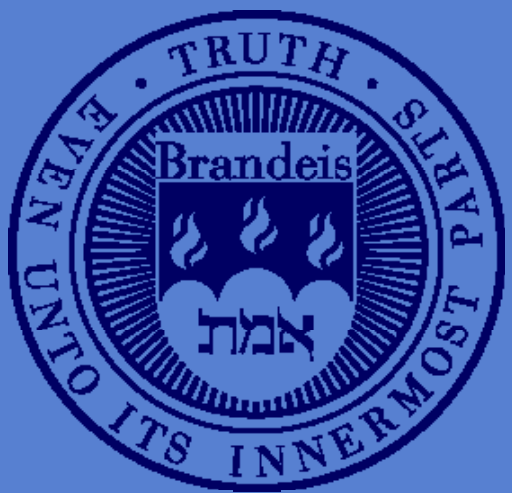

China's New Lost Generation: The Casualty of China's Economic Transformation

Gary H. Jefferson, Department of Economics, Brandeis University 


\title{
China's New Lost Generation: The Casualty of China's Economic Transformation
}

\author{
Gary H. Jefferson \\ jefferson@brandeis.edu
}

July 24, 2016

Forthcoming: Journal of Chinese Economic and Business Studies

\begin{abstract}
China's surge into global middle-income status over the space of three decades has been spectacular. However, a potentially large and burdensome cost has been imposed on a generation of adolescents and young adults who abandoned the countryside, and with it access to basic education, in order to seek the anticipated advantages of jobs in the country's burgeoning urban-industrial sector. This large swath of off-farm migrants transformed China. It propelled China to the status of the "world's factory" and created the scale and accumulated learning-bydoing enabling China's transition to a "knowledge economy” that no longer depends on the labor of China's new "Lost Generation.” As the Lost Generation and its left-behind children, who suffer from a chronic lack of schooling, thicken the lower tail of China's income distribution, it may be the rising, prosperous urban middle class that ultimately incurs the social, economic, and political challenges associated with China's generation of off-farm migrant households once essential for launching China’s economic ascent.
\end{abstract}

JEL classifications: J21, J24, J31, O15, O33

The author deeply appreciates the editorial suggestions offered by Andrea Oseas. 


\section{Introduction}

Since 1980, China has dramatically transformed its relatively backward and inefficient economy into an immense industrial economic system with the world's largest industrial workforce producing the most industrial output and generating the largest volume of exports in the world. A major source of this transformation has been the huge exit of workers from agriculture to industry. Zhang, Huang, and Rozelle (2002, p. 38) start their paper with the following summary:

The massive flow of labor into the off-farm sector has brought new prosperity to millions of rural households during China's economic reform era. The proportion of the rural labor force that has entered the labor force rose from around 22\% in 1988 to 34\% in 1995 (Rozelle et al., 1999). By 2000, nearly 200 million people (or about $40 \%$ of laborers) held off-farm jobs. The rise in wage earnings and income from self-employed activities has created most of the increase in rural incomes in the late 1980s and 1990s (Parrish, Zhe, and Li, 1995; Rozelle, 1995).

The authors' summary account of the surge in off-farm employment and living standards during the 1980s and 1990s is impressive. By any measure, hundreds of millions of Chinese residents graduated from poverty during this period. Most likely, in terms of the sheer number affected and the extent of improvement, the number far exceeds any other two-decade economic transformation in human history. Ironically, the achievement described by Zhang et al. above also created the likelihood of challenging conditions that are now emerging and will probably persist for decades to come for tens of millions of the off-farm industry migrants.

In August 1966, approximately 20 years before the beginning of the surge in off-farm migration celebrated by Zhang et al. (2002), Mao Zedong launched the Cultural Revolution by sending young Red Guard youth from China’s cities to the countryside. Two years later the Party broadened the urban-rural migration by issuing an order to every urban household: at least one of their teenage children needed to leave the city indefinitely to contribute to rural farm work. The tumult resulting from this political command, requiring that the privileged urban "intellectual" youth learn from farmers and workers, persisted from 1968 until the mid-1970s.

According to Chinese sources, across the country, as many as 17 million "intellectual youths" packed their bags and moved to some of the most remote parts of China, where they 
transformed from urban-dwelling students to farmers. ${ }^{1}$ With many schools in China's cities ranging from primary schools to universities having been shut down thus displacing China's urban youth from its formal educational mission, ${ }^{2}$ this urban generation of the late 1960s and early 1970s has come to be known as China’s Lost Generation. The contrasts with China's offfarm migrants of the late 1980s through the 1990s are stark: the post-reform migrations being purely voluntary rural-urban relocations in service to China’s capitalist transformation; contrasted with the politically-enforced, urban-rural, anti-capitalist disruption of the earlier Cultural Revolution. Nonetheless, the large-scale displacement of the migrants from the classroom during the early decades of China's Economic Reform have likely amounted to the loss of hundreds of millions of school years, which, associated with the increasingly dead-end nature of largely low-skill occupations, may be setting the stage for China's New Lost Generation.

Ironically, in the process of establishing China as the "world's factory" China's off-farm migrants have created four conditions that are severely dimming their prospects for their own longer-run household prosperity; these are:

1. terminating their education so as to limit their future employability;

2. substantially diminishing the supply of China's surplus labor, moving China toward its Lewis Turning Point, thereby putting upward wage pressure on China’s low-wage employers.

3. creating "the world's most extensive manufacturing ecosystem" that has in turn enabled “...continuous innovations in production processes that reduce costs and improve quality” (McKinsey 2015, p. 7); that is, creating the capacity for Chinese industry to move up the technology ladder.

4. as a result of \#2 and \#3, severely reducing the supply of semi-skilled, low-wage jobs upon which China's first generation of off-farm migrants have largely depended so as to render larger portions of this population substantially under employed and unemployable.

\footnotetext{
${ }^{1}$ CNN World (Tracy You), "China's 'lost generation' recall hardships of the Cultural Revolution," http://www.cnn.com/2012/10/24/world/asia/china-lost-generation/

${ }^{2}$ During the period 1966-1970, China's Ministry of Education suspended its reporting of the breakdown between urban and rural school enrollments. When the reporting resumed in 1971, the proportion of middle and high school students reported as rural enrollments rose from just 31.9\% in 1965 to $70.9 \%$ in 1971. (Hannum, 1999, Table 1).
} 
Broadly defined, the early generation of off-farm workers in their early adolescent and adult years had their employment opportunities bracketed by the proliferation of low-wage, lowskill jobs associated with China's initial rural industrialization during the 1980s followed by the surge of foreign direct investment beginning in the mid-1990s and peaking shortly after China's ascension to the WTO. The exit of tens of millions of workers from the farm sector substantially diminished the supply of rural surplus labor, thereby effectively moving China toward the socalled Lewis Turning Point. The consequent emergence of reported labor shortages has occasioned a mix of alarm and satisfaction that these shortages have begun to force a general restructuring of the Chinese economy. This analysis generally focuses on the period 20-year period from 1985 to 2005 as that during which China's generation of rural youth, referred to in this paper as the New Lost Generation, became most at risk for becoming entrapped in the dynamic of dropping out of school and migrating off-farm for destinations that have generally led to transient, dead-end employment.

The following sections document and analyze this phenomenon of China New Lost Generation. Section 2 relates the theoretical framework for understanding the mass migration of China's excess supply of rural labor to the actual circumstances of the 1985-2005 period. Section 3 examines the educational profile and schooling choices relating to China's rural sector. Section 4 analyzes the supply of surplus labor, including the Lewis Turning Point. Section 5 identifies the drivers of China's industrial transformation during this period. Section 6 analyzes the impact China's off-farm migration phenomenon on the children of the migrants. Section 7 draws conclusions from the analysis.

\section{The theoretical setting: the 2-sector model}

This economic logic of China's industrial transformation is captured in the two-sector economic growth model of Lewis (1955) and its more formal representation and extension by Fei and Ranis (1964). In this model, the rural agricultural sector is populated by substantial quantities of excess labor, forcing the marginal product of farm labor to hover in the range of the subsistence wage or even falling to near zero. Life is sustained through the establishment of formal and informal collective village or family arrangements that distribute income and consumption goods to enable subsistence levels of living standards. Coincident with this rural 
condition is an emerging industrial sector in which investment and technology transfer results in the robust growth of labor demand and shifting out of labor's marginal product schedule. As the demand for labor rises, wages in the industrial sector rise above the subsistence wages that had been paid to the diminishing numbers of underemployed surplus rural workers. As long as the continuing rise in industrial wages is sufficient to draw workers with the requisite skill levels from their rural settings, the growth of the urban industrial sector will motivate low-wage farm workers to abandon their farm work and migrate to the urban industrial sector to secure more lucrative employment.

This Lewis and Fed-Ranis two-sector has direct relevance to China. The Household Responsibility System (HRS) spread rapidly over the Chinese countryside during 1980-1983. Full official recognition of the HRS as universally acceptable was given in late 1981; at that time, 45.1\% of production teams in China had already switched to this system. By the end of 1983, 94.2\% of households in China's rural areas had adopted it. ${ }^{3}$ It is well documented that the adoption of the HRS led to dramatic increases in China's agricultural productivity and rural living standards. Poverty rates fell dramatically. While gross agricultural output increased by nearly 90\% (NBS, 2008, p. 448), rural agricultural employment expanded by just 6.9\% (NBS, 2008, p. 114). Although irrigated area declined by 0.5\% (NBS, 2008, p. 451), over this 3-year period, the number of small tractors more than doubled (NBS, 2008, p. 450) while the consumption of chemical fertilizer and electricity, both increased by approximately 50\% (NBS, 2008, p. 451). As a result of more efficient crop mixes and improved labor allocation and incentives, as well as the growth of complementary inputs, labor productivity in agriculture rose dramatically, nearly doubling.

One curious feature of the surge in China's measured agricultural productivity stands out. During 1980-84 when the household responsibility system (HRS) unfolded, labor productivity growth in the agricultural sector rose robustly at approximately 8\% per year. Notwithstanding the fact that wholesale decollectivization did not begin until 1980, we see that during 1977-79, prior to the implementation of the HRS, China also experienced a surge in agricultural productivity as crop output rose by $17 \%$ during this 2-year period, while reported labor rose by only slightly more than one percent. This surge, beginning in 1977-78 and continuing until 1985 is shown in Figure 4 (Yang and Li, 2008).

\footnotetext{
${ }^{3} \operatorname{Lin}(1987)$.
} 
According to Lin (1989), the key change in this time was the substantial increase in stateabove quota contract prices, an increase of more than $40 \%$ relative to 1978 versus less than a $3 \%$ increase since 1970. These changes in crop prices, both state procured and market prices appear in Yang and Li (2008), Figure 1.

What is not highlighted is the concurrent dramatic decline in school enrollments that corresponded to the robust rise in crop prices, state procurement and otherwise. During 1978-85, official statistics show the number students graduating from primary school declining from 22.88 million in 1978 to 20.53 million in 1980 and 20.00 million in 1985; over the same period, the number of new student enrollments in junior secondary school declined more precipitously from 20.07 million in 1978 to 15.51 million in 1980 and 13.49 million in 1985. (NBS, 2012, Table 20-7 and 20-07, pp. 752-753). The 1985 figures represent the smallest cohorts in the 1980s, until 1988 when, most likely as a result of the One-Child Policy, the primary school population begins to drop off.

These figures are of interest in this context principally because they may be a harbinger of the responsiveness of school enrollments to economic incentives, first during the post-1977 period as procurement prices and institutional reform combined as powerful incentives to mobilize household labor on behalf of agricultural production, and then following 1985 as rural and urban industrialization surged to reallocate farm labor to factory employment. The decline in school enrollments beginning as early as 1978 may well have reflected the responsiveness of adolescent and young adult labor to employment incentives across China's transforming economy.

\section{China's education profile}

In making their migration decision, China’s rural youth generally confronted a choice between a life engaged with work in agriculture, possibly mixed with secondary (industry) or tertiary (service) sector employment and relocation to a job in industry or construction. During the late 1980s into the 1990s, this rural cohort generally completed primary school, became literate, but did not complete lower middle school and only infrequently enrolled in upper-middle school. 
In an extensive interview of migrants within Guangdong province, the survey team in their report Primary Migration Motivation: "Why I left the Village" (Hu, 2012) asked the "new generation" migrants to explain their decisions to leave the farm-education setting for urban employment. They summarized the response as follows:

In the interviews, we asked each of the migrant workers the question of why they first decided to migrate out of the village. Instead of having been pushed by harsh economic times in the village, it turns out many were pulled by opportunity and the excitement of city life. Interestingly, being tired of school was one of the most frequent answers to the primary migration motivation question, surpassing economic reasons. Many of our interviewees expressed little interest in school and did not complete their compulsory nine years of education before migrating. A secondary reason emerged, however, for not finishing school: the inability or unwillingness to pay for schooling when job opportunities in cities became available. After dropping out, the Chinese school enrollment structure all but precludes youth from going back to school and continuing their education where they left off.

According to the report, the National Bureau of Statistics report found that the first migrating age of migrants born between 1980 and 1990 is 21.1, while the age for those who were born after 1990 is 17.2 - considerably younger. Having migrated after limited years of schooling, migrants face high pressure from work, low satisfaction in terms of their wages, unsure selfidentification (villager or citizen), and an overall lack of happiness.” (Hu, 2012).

First, we look at the nationwide distribution of school enrollments and achievement. While not a precise measure, Table 1 attempts to measure the proportion of young children in the 0-14 age bracket that graduate from lower secondary school, i.e.. typically with 9-years of schooling. The figures show a graduation rate of less than $30 \%$ in 1982, rising to the range of $35 \%$ to less than $40 \%$ during the period $1987-1995$. Thereafter the rates rise rapidly to $55 \%$ in 2000 and three-quarters in 2005 and 2010. In order to understand the implications of these figures for China's rural-urban divide, it helps to understand that in 1986 the Chinese government promulgated a regulation that required 9-years of compulsory schooling. However, this requirement was to be phased in. According to Hannum (1999, pp. 200-201), “Cities and economically developed areas in coastal provinces and some parts of the interior where onequarter of the population resides were expected to universalize 9-years of compulsory education by 1990. Elsewhere, as Hannum describes, semi-developed areas representing about one-half of the population were expected to satisfy the regulation by 1995, whereas the underdeveloped 
regions accounting for the remaining one-quarter of the population were expected to achieve universal elementary education with a target for universalizing lower secondary education. Table 1 suggests that there was little change by 1990 and some marginal improvement by 1995 but notable gains only materialized toward 2000 with substantial gains showing in 2005, nearly 20 years after the adoption of the Compulsory Education Law.

The statistics in Naughton's Table 8.2 for China’s population over 15-years of age are largely consistent with this account. They show stagnant shares of the population gaining only an elementary school education from 1990 to 1995, with little gain in the proportion of junior secondary school graduates. Also, over the period 1982-1995, the share with upper-middle school and college degrees only grew from 10.2 to $11.7 \%$. Note that beginning in 2000 , Naughton's table shows the beginning of substantial gains at the upper end of schooling as the proportion with upper-middle school or college degrees rose from $11.7 \%$ in 1995 to $19.2 \%$ in 2000.

According to Figure 2, the Statistical/OECD chart, by 2014, the proportion of 25-34 year olds without a high school degree in China stood at 64\%, indicating that the proportion with a high school education stood at 36\%. Given the focus on 25-34 year-old students, this result indicates that during the 2000-2010 period, when this cohort was of high school age, a relatively small proportion China's youth were achieving high school educations. The fact that the compulsory education requirement appears to have only been effectively in force in 2000 for the coastal population and the more advanced interior urban areas, suggests that a very small proportion of China's rural population could be counted among the young adult population with at least a high-school degree.

As indicated above, the overall national enrollment figures seriously obscure the disparity between rural and urban enrollment profiles. According to The Economist (Aug 23, 2014), in 1990, when off-farm migration was a well-established feature of China’s industrializing landscape, only $7 \%$ of rural students entered upper middle-school. Explaining this dismal statistic, The Economist elaborated:

"Some quit school because of the cost, in contrast to many other countries, the upper years charge for tuition. Senior middle-schools are often far away from villages, so students have to board. Including the cost of books, the bill for three years can easily amount to thousands of dollars - more than a year's income for poorer rural families. About half fail the test to get into senior middle-school. Others leave because they can 
get what they consider a decent job. Wages for low-skilled work have increased greatly in recent years...."

Table 2, Figure 3.6 and Figures 3.2 and Figure 3.3 explicitly document the disparity between educational outcomes in China's rural and urban areas. In Table 2, Zhang, Rozelle et al. (2002) report their results for the number of years of schooling obtained by males and females for the years 1988, 1992, and 1996. Despite the bump in 1992, these show no improvement from 1988 to 1996, during which the average male student barely received more than 6 years of primary education, whereas the females come up substantially short of closing in on a primary school degree.

As shown in Figure 3.6, Ou (2005) and Rozelle (2011) show how China’s deep ruralurban educational divide has its origins in early childhood. This diagram compares the “educational readiness” of China’s children aged 4-5 in urban areas. The authors, Ou (2007) and Rozelle (2011) report that the lower “critical threshold” for preparation to succeed in primary schooling and beyond is 70. Ou (2007) shows a mean $=100$ for the distribution of urban readiness; based on survey work in Gansu Henan, and Shaanxi, Rozelle (2011) reports that even the mean of rural child educational readiness lies below the basic readiness threshold.

One explanation for this poor rural showing is shown in Figures 3.2 and 3.3. These show the incidence of anemia in rural children under 5 years (Fig. 3.2). ${ }^{4}$ Because the symptoms of anemia entail serious impediments to normal physical development and learning readiness, the incidence of anemia is likely to be highly correlated with educational readiness. As shown in this figure, in 2005, in rural areas, $40 \%$ of the children under one-year old exhibited the symptoms of anemia. In the rural poor areas, as late as 2009, this figure exceeded $40 \%$.

One of the research objectives of Zhang, Huang, and Rozelle (2002) is to “...to examine if education in different time periods - the late 1980s, the early-1990s and the mid-1990s - can be associated with increasing access to off-farm jobs.” The author's hypothesis is that if rural labor markets are improving, the survey data should show that access to off-farm work improves and wages rise with education; also, the relationship should become stronger over time. The study by Zhang, Huang, and Rozelle clearly shows that education affects the ability of the

\footnotetext{
4 “Early life ID affects at least 3 major neurobehavioral domains, including speed of processing, affect, and learning and memory, the latter being particularly prominent. The learning and memory deficits occur while the infants are iron deficient and persist despite iron repletion. "Stephanie J. B. Fretham, Erik S. Carlson, and Michael K. Georgieff, "The role of iron in learning and memory," http://advances.nutrition.org/content/2/2/112.full
} 
household to take advantage of off-farm employment opportunities in rural China and that this tendency is rising over time. In all three years of their surveys -1988, 1992, and 1996 - individuals with a middle school education and above have higher off-farm participation rates (Table 3, rows 1 and 2). Perhaps more importantly, the difference between those with less and those with more education is expanding sharply over time. In 1988 and 1992 the off-farm participation rates of those with middle school or above exceeded that of those with less education by around 50 percent. By 1996, however, the youth with middle-school degrees had off-far participation rates that were more than twice those without middle-school degrees. The relationship between education and wages also has changed during the reform period (Table 3, rows 5 to 10). In the late 1980s, wages for middle school graduates and above were actually below those who had only graduated from elementary school education (in the middle-aged and old-aged categories). By the mid-1990s, however, a sharp reversal had occurred. For all age groups, those with a middle school education and above earned more on a per day basis than those with only an elementary education. Across all age categories, the real wage rose more than 10 percent faster annually between 1988 and 1996 for those with higher education levels when compared to those with only elementary schooling.

One report, however, a National Bureau of Statistics report cited by Hu (2012) finds changes in migration age structure that are not entirely consistent with Zhang et al.'s result. That is, the report found that for migrants born between 1980 and 1990, the first migrating age was 21.1, while the age for those who were born after 1990 was 17.2 - considerably younger. However, one way of reconciling the finding of more rural adolescents extending their schooling into middle school is that unlike the initial cohort, almost immediately upon finishing their schooling, the more recent youths are departing for their off-farm work destinations.

These results indicate that China's rural labor market has become more efficient during the period analyzed in this paper - a more efficient machine for matching school dropouts and graduates with jobs that match the education, skill, and wage profile of migrants and industrial employment. The results indicate that while initially, through their labor-market encounters, China's rural youth faced a negligible incentive to remain in school, so that they might acquire the skills to qualify for a higher wage, increasingly secondary school graduates were rewarded for extending their education in relation to their counterparts who chose to select off-farm labor 
after graduating from primary school. This condition may help to explain the rise in seniorsecondary school graduation rates in 1996, which had been falling steadily from 1987 to 1995.

\section{Supply of surplus labor: The Lewis Turning Point}

Section 2 sets the theoretical framework for understanding the strategic calculus of the Lost Generation in deciding to migrate for off-farm employment and therefore forgo, at least for the immediate future, schooling and participation in China's farm economy. According to national statistics, by the end of 2009, China had a total of 229.8 million rural migrant workers. Among them, 145.3 million rural migrant workers worked outside of their hometowns for a period over six months and almost 84.5 million worked within their hometowns for a period over six months. Around $70 \%$ of migrant workers are employed in China's eastern areas with two thirds of them working in large or medium cities and half of them moving between different provinces. Approximately $60 \%$ of migrant workers are mainly concentrated in manufacturing and construction. ${ }^{5}$

China's labor shortage has arisen not only as a result of the extensive hollowing out the large pool of surplus labor via off-farm migration, the growing shortage is becoming yet more severe with secular declines in the rates of population growth and new labor force entry. The decline in labor force growth is the culmination of the second and third generation of families that have formed under initiatives of the Chinese government to depress fertility. These began with the government's campaign in the 1970s to encourage "later marriage, longer intervals between children, and fewer children" using a variety of birth control means. This then culminated with the One-Child Policy that was formally adopted in the 1980s. The population effects of such campaigns do not happen immediately within the space of a single cohort. Their impacts occur through two channels. The first, which may materialize in the near term, is a reduction in women's total fertility rates, say from 3 to 1.5. The longer-term effect is the sheer reduction in the number of child-bearing women, an effect that cascades from generation to generation, so that two to three generations into the fertility reduction campaign, there may be

\footnotetext{
${ }^{5}$ International Labor Organization, "Labor migration in China and Mongolia," http://www.ilo.org/beijing/areas-ofwork/labour-migration/lang--en/index.htm
} 
only half as many women of child-bearing age, each bearing fewer children than the larger cohort of their grandparents.

We see this decline most starkly in Table I, which shows the number and proportion of the population represented by China's youth in the range of 0-14 years old. In 1982, the 14 and under population consisted of 341.46 million persons, representing one-third of China's total population. By 2000, the 0-14 population had declined to 290.12 million down to $22.9 \%$ of the population. During 2000 to 2010, the decline accelerated by 57.5 million to 222.59 million, $16.6 \%$ of the population accounting for just one half of the total population that it had accounted for in 1982.

As a result of the confluence of these inter-related factors - the precipitous decline in China's young population and depletion of surplus labor in the farm population - China's working age population has reached an historical peak and has begun a rather dramatic secular decline. While Das and N'Diaye (2013) anticipate that the reallocation of surplus labor from the rural sector will drive the Chinese economy to the Lewis Turning Point during 2020-2025, it is not clear that they have fully taken into account the overall decline in the growth of population and the labor force. In any event, Chinese manufacturers appear already to be taking the technology upgrading required to address the growing labor shortage and attendant surge in industrial wages. ${ }^{6}$

5. Industrial development and technology upgrading in Chinese industry

Between 1980 and 2013, total employment in China has grown from 423.6 million to 769.8 million. Over this period, industry's employment share grew from $18.2 \%$ to $30.1 \%$. Within the industrial sector, the composition of enterprise ownership and employment changed dramatically. Industry productivity growth and technology advancement have been robust throughout the reform program, with China increasingly transforming from an imitation economy to an innovation economy.

Following the beginning of economic reforms, China's off-farm industrial landscape initially began its transformation with the township and village enterprises, whose ownership

\footnotetext{
${ }^{6}$ For a summary of recent research on the subject, see The Economist, "China Approaching the Turning Point," January 31, 2013, http://www.economist.com/blogs/freeexchange/2013/01/growth-and-china
} 
converted from communes and collectives of the socialist period to factories that proliferated and expanded rapidly throughout the countryside. From 1980 to 1996, TVE employment rose from 30 million, representing 9.4\% of total rural employment, to 135.1 million, having grown to $27.6 \%$ of China’s total rural employment. (NBS, 2014) After peaking in 1996, TVE employment trailed off as TVEs were forced to restructure substantially. With increased market integration and competition, official discrimination against TVEs, and official preference for foreign-owned enterprises, TVEs lost their competitive position (Naughton, 2007).

During 1995 to 2005, overall industrial employment stalled, growing by just 11.3\% over the decade compared with having more than doubled from 1980-1995. Later, during the subsequent decade, from 2005-2013, industrial employment grew by over one-third. (NBS, 2014) The 1995-2005 slowdown most likely reflected the episodes of "xiagang” and "jueda fangxiao," the privatization of thousands of SOEs accompanied by the "furlough" of tens of millions of workers in the state sector. Based on Ministry of Labour and Social Security (MOLSS) figures, 21 million workers were laid-off from SOEs between1994 and 2005; when laid off workers from collective enterprises were included in the calculations, the total number increased to 30 million. ${ }^{7}$ During this time, there was a compensating surge in private employment in the industrial sector of close to thirty million workers and another six million jobs in the combined foreign and Hong Kong-Macao-Taiwan sectors. Furthermore, during 1985-2005, we see construction jobs having more than doubled from 20.4 million to nearly 42 million (NBS, 2007, p. 114).

Hence, during the 20-year period on which we focus, the principal surge in industrial employment transpired over the decade 1985-1996, during which China’s total industrial employment grew from 103.8 million to 162.0 million. During the subsequent decade, 19952005, as the composition of industrial growth and employment moved away from the state sector toward the private and foreign/overseas-funded sectors, it is likely to have also shifted from China's urban core increasingly toward the urban periphery, thus making the growth of industrial and construction employment more accessible to off-farm migrant labor.

Notwithstanding exceptionally rapid employment growth during the reform period, during 1985-95 labor productivity grew at an annual exponential rate of 8.20\%; during the next

\footnotetext{
${ }^{7}$ China Labor Bulletin, "Reform of State-Owned Enterprises in China," http://www.clb.org.hk/content/reformstate-owned-enterprises-china\#7b
} 
10-year period, 1995-2005, with slower employment growth, productivity grew at an annual rate of $8.54 \%$. Finally, during the 2005-2015, productivity grew at an annual rate of $6.93 \%{ }^{8}$. These rates are rather extraordinary. Given that during 1985-2015, Chinese industry has been converging toward the international productivity frontier, causing catch-up to be increasingly difficult, ${ }^{9}$ maintaining high levels of productivity growth is a notable achievement. The fact that employment growth was able to accelerate during the past decade even as productivity growth continue its robust rate of growth is rather impressive.

This sustained increase in labor productivity growth has translated into not only higher levels of productivity, but also higher wages. According to a 2014 survey by the Japan External Trade Organization, the total annual cost of a Chinese manufacturing worker (including salary, benefits, social security payments and bonuses) is $\$ 8,204$, compared to $\$ 4,481$ in Indonesia, $\$ 3,618$ in India, ${ }^{10} \$ 2,989$ in Vietnam, and $\$ 1,580$ in Bangladesh.

A number of inter-related features of the $21^{\text {st }}$ Century Chinese economy underscore its drive to achieve a level of technological sophistication comparable to that of its OECD counterparts. Two conditions, in particular, are enabling China's technology transformation. A key measure of China's search for more advanced technologies has been the surge in R\&D spending. China's R\&D intensity, just $0.5 \%$ in 1990 and $0.6 \%$ in 1996, commenced its surge in the late 1990s, reaching $1.8 \%$ in 2010 , rising to the current range of $2.2 \%$. As such, China is the only middleincome country to be in the 2-3\% GERD range which heretofore has been achieved only by a select group of OECD countries and smaller economies, notably Singapore and Taiwan. This intensification of R\&D spending is a measure of and harbinger of China's move up the industry technology ladder as China's leadership strives for the economy to become "a knowledge economy" and an "innovation economy." China now leads the world in patent applications. While many of these are lower quality patents, the numbers of both home-grown invention patents and invention patents is growing substantially faster than those of the U.S. Japan, and the EU.

As the World Intellectual Patent Office reported in 2015, "Patent offices receiving the highest number of applications in 2014 were China, with 928,177 filings, followed by the US $(578,802)$, Japan $(325,989)$, the Republic of Korea $(210,292)$ and the European Patent Office

\footnotetext{
${ }^{8}$ Computed by the author, based on NBS yearbook data.

"Or as Gershenkron (1966) would characterize it, the "advantages of backwardness" would diminish.

${ }^{10}$ Survey of Japanese-Affiliated Firms in Asia and Oceania (FY2014 Survey), December 2013.
} 
(EPO, 152,662)." WIPO goes on to speculate that its $12.5 \%$ growth of patent filings in 2014, China's State Intellectual Property Office (SIPO) is set to become the first office to receive a million applications in a single year. China. In terms of international patents filed abroad, US applicants filed the most applications abroad $(224,400)$, followed by those from Japan $(200,000)$ and Germany $(105,600)$. By contrast, Chinese applicants filed comparatively few applications abroad - only around 36,700. ${ }^{11}$

The second condition enabling China's industrial technology upgrading is captured as the central theme of a McKinsey and Company report (2015, p. 7). According to McKinsey, having established "the world's most extensive manufacturing ecosystem," Chinese manufacturing is able to achieve "the continuous innovations in production processes that reduce costs and improve quality.” According to McKinsey, China’s unique manufacturing ecosystem has given its manufacturing economy two major innovation advantages. The first, resulting from a combination the rapid growth of exports during 1990 to 2010 and its large and fast-growing domestic market is a large, fast-growing, and increasingly higher-income customer base that is driving its capacity for customer-focused innovation. Minor, incremental, but cumulatively significant, product innovations, such as those appearing in smart phones, renewable energy, and automobiles enable China to close in on the global cost-quality frontier across an increasingly wide rate of consumer goods. A second, related, consequence of its manufacturing ecosystem is its ability to achieve efficiency-driven innovation centered on incremental innovations that improve production efficiency. Both of these - customer-based innovation and efficiency-driven innovation - accrue through the reach and intensity of its manufacturing economy to generate both learning by doing on the factory floor and learning by using in the market place - trial, error, and customer feedback from China’s rapidly growing middle class.

A persistent myth about Chinese manufacturing is that the country is only good for assembly, with the more profitable parts of the operation, such as design and marketing, remaining in the West and Japan. However, the Economist (March 14, 2015) reported a finding of the World Bank: "The World Bank has found that the share of imported components in China's total exports has fallen from a peak of $60 \%$ in the mid-1990s to around 35\% today. This is partly because China boasts clusters of efficient suppliers that others will struggle to replicate.

\footnotetext{
${ }^{11}$ World Intellectual Property Office, "Global Patent Filings Rise in 2014 for Fifth Straight Year; China Driving Growth," Geneva, December 14, 2015, PR/2015/786.
} 
It has excellent, and improving, infrastructure:... And its firms are using automation to raise productivity, offsetting some of the effect of higher wages - the idea behind the government's new “Made in China 2025” strategy.”

Accounts of industrial upgrading through Chinese manufacturing abound. One illustrative example is that of Chu and Davis, ${ }^{12}$ which explains how Levi Strauss \& Co. began is introducing radical technology upgrades into the production of its iconic jeans in China. According to Chu and Davis, “Over the coming decades, a labor shortage will force Levi and scores of other Western brands to remake their China operations or pack up and leave. The changes will mark a new chapter in the history of globalization, where automation is king, nearness to market is crucial and the lives of workers and consumers around the world are once again scrambled.” They further recount how fearing that China will see an exodus of manufacturers, Chinese Communist Party Chief Xi Jinping last year called for "an industrial robot revolution” in China, which has become the world's largest market for automation.

Firms are also pursuing lower wages deeper into China. Foxconn once based its China operations mostly in Shenzhen, the manufacturing hub near Hong Kong. It now has large plants in Henan and Sichuan provinces, and is building a facility in Guiyang, one of China's poorest regions. Furthermore, portions of China's lower-wage production are passing to large lowincome populations in South-East Asia. However, as reported by The Economist (March 14, 2015), “...as Samsung, Microsoft, Toyota and other multinational firms trim production in China and turn instead to places such as Myanmar and the Philippines, they reinforce a regional supply chain with China at the centre.”

This account of rising productivity and rising wages, raises the question of whether rural youths who had fit into assembly line production, will be able to acquire the training, experience and skills to equip them to compete effectively in China's evolving labor market, into which increasing numbers of youths and young adults with elite high school and college degrees are entering. In the following section, we speculate on the intergenerational impacts of the transformational change in China's industrial structure and demography over the past three decades.

\footnotetext{
${ }^{12}$ Kathy Chu and Bob Davis, "End of Cheap Labor: As China's Workforce Dwindles, the World Scramble's for Alternatives," Wall Street Journal, http://www.wsj.com/articles/as-chinas-workforce-dwindles-the-worldscrambles-for-alternatives-1448293942
} 
6. The New Lost Generation: Intergenerational impacts

Section 3 above, the educational profile, affords some sense of the cost associated with the off-farm migration phenomenon. Although we do not know if the opportunity or practice of migration is itself responsible for the poor quality and limited outcomes of China's rural educational system, we find reports that the erosion of China's rural school population is compromising the quality of China's rural education. The China Daily reported the findings of a 2012 report by the Education Institute of Beijing Institute of the Technology. According to the China Daily account ${ }^{13}$ :

The number of rural school pupils has dropped to a ten year low with more than 60 schools closing every day, a report on countryside learning revealed. From 2000 to 2010, some 63 primary schools, 30 teaching schools and 3 junior schools closed on average every day in the countryside. From 2000 to 2010, the number of countryside primary school pupils decreased by 37.8 percent while the number of junior students decreased by 26.97 percent. More than 300,000 countryside schools and learning institutes closed over the same period, while 10,600 junior schools closed. The report (by) claimed the decline of the school-aged population has led to the decline of rural schools, with many parents migrating to cities to find work. (The President of the Institute), Yang Dongping...claims the large scale removal of countryside schools led to the gradual decline of rural education and excessive merging of schools, leading to long travel and high tuition fees. "The large continuous merging of schools has resulted in not only the dropout of lower grade students, but even worse, a great deal of students cannot enter school which means it is possible more than a million illiterate people will appear every year," said Han Qinglin, the inspector of Hebei Education Department and the director-general of the rural education branch of the Chinese Education Society.

In all likelihood, as China's urban-rural income inequality has grown in recent decades, enabling China's emerging urban middle class to dedicate ever more household resources to schooling their single children, it is likely that the rural-urban education quality gap has expanded further. Below, we examine certain other consequences of the pattern of migration: the impact on the children of migrants and the implications for inter-generational income inequality.

Implications for educational opportunities for migrant children. According to a 2005 survey, there were 18 million migrant children (0-14) of which one third were migrants to big cities, one third migrants to counties and towns, and one third were internal migrants within their

\footnotetext{
13 "Rural school pupils drop to 10-year low," Nov. 20, 2012, http://www.chinadaily.com.cn/china/201211/20/content 15944175.htm
} 
counties of origin. Meanwhile, as a result of adult migrants, there are 60 million children leftbehind (0-14) in their hometown. (Han, 2009)

Formal (or “permanent”) moves - meaning those involving a hukou change -- crossing city, town and township boundaries are strictly regulated and require approval by the public security authorities. Generally speaking, it is very difficult for an ordinary persons to change hukou from rural to urban areas, or from smaller cities to larger cities (Wang, 2005; Chan, 2009a). The New Compulsory Education Act which was revised to cover migrant children in 2005, nearly 20-years after it first took effect, relies on weak provisions and has yet to break through the Hukou-based registry oriented enrollment principle. Therefore, for the period 19852005, for the children of our Lost Generation, the law did not attempt to resolve the systematic barriers to educational opportunity to migrant children residing under the hukou system.

From their multivariate analysis of school enrollment, using data from Guangdong Province for the 1995 China 1\% Population Sample Survey, Liang and Chen (2007) report two major findings. First, temporary migrant children were much less likely to be enrolled in school compared to local children. Temporary migrants with less than one year of residence in cities suffered the most. Perhaps somewhat surprisingly, permanent migrant children were more likely to be enrolled in school than local children; the authors speculate that this disparity arose due largely to the highly selective nature of their parents who themselves had often had the qualities to manage a successful life transition to a new location and orchestrate their family's access to local services notwithstanding the obstacles inherent in the hukou system. Liang and Chen’s second finding is that also in rural areas, compared to non-migrant children established in a place of origin, rural temporary migrant children from Guangdong also encountered a major disadvantage in terms of school enrollment. As education has become increasingly important for socio-economic mobility in Chinese society, such disadvantages faced by temporary migrant children are likely to have detrimental and long-term consequences for migrant children and for urban society as a whole.

Chang, Dong, and MacPhail (2011) assess the impact of internal migration on the time allocation patterns of the left-behind elderly and children in rural China, 1997-2006. The proportion of children with migrating parents is increasing, with 26.6\% in 1996 having at least one parent migrating, rising to $34.4 \%$ in 2006. Their multi-variate analysis, based on data from the China Health and Nutrition Survey (CHNS), demonstrates that the migration of household 
members results in increases in the time spent on farm work and domestic work by the leftbehind elderly and children. The survey shows a rising proportion of households with one or more family members relying on the household work of elderly family members; the proportion rises from $40.0 \%$ in 1996 to $48.3 \%$ in 2006. Eighty percent or more of the time, the migrating parent is the father. The survey makes clear that the phenomenon has fundamentally altered the nature of family structure in China's rural sector, fragmenting the traditional 2-parent family structure, while disbursing the children over a depleted rural education system and second-tier migrant education system, both of which are far inferior to the range of schooling opportunities accessible to city residents. Migration has a striking gender differentiated impact, with the increase in work time being greater for elderly women and girls than elderly men and boys. Thus, the authors find that non-migrant left-behind children - the children of departed migrant patents - suffer from poorer schooling outcomes relative to intact non-migrant families.

Disparities in intergenerational educational opportunities. In 2010, China’s State Council approved an ambitious plan of nationwide education reform. ${ }^{14}$ The development of education, ranging from pre-school to vocational education in rural areas, will be a priority in the country's overall development program, according to the plan. The National Middle- and LongTerm Education Development Blueprint was meant to set the tone for enhancing the country's education sector, which has long suffered from problems ranging from funding shortage to unbalanced development between rural and urban areas. The blueprint sets the total budget for education at $4 \%$ of gross domestic product by 2012, or a 0.52 percentage point increase from 2008. The world's average was $4.5 \%$ in 2008.

The blueprint also pledges to narrow the educational gap between rural and urban areas by building more schools, providing more teachers and enrolling more high school graduates into college from rural, ethnic minority-dominated or less developed regions. Among the other features in the plan, pre-school education will be available to every citizen by 2020, at least 90 per cent of middle school graduates will continue to high school, more than 40 per cent of high school graduates will go to university, and an average citizen should receive at least 11.2 years of education.

\footnotetext{
${ }^{14}$ Reported in the South China Morning Post, "Huge Education System Upgrade," May 7, 2010, http://www.scmp.com/article/713615/huge-education-system-upgrade
} 
In 2012, nearly 25 million students in China were enrolled in high school compared with just 7 million in 1995, when the relevant age cohort was approximately 1/3 larger than it was in 2012. At the university level, in 2012 nearly 24 million were enrolled for bachelor's degrees compared with less than 3 million in 1995. Most certainly, in 1995, very few of the high school and university students were rural residents, off-farm migrants, or the children of off-farm migrants. One implication of this surge in higher-level schooling is that for the technologyenhanced jobs that are now coming on line across Chinese industry, the more than 10 million students who are emerging today from China's substantially upgraded high school and university system are far outcompeting the off-farm migrant population, now in their mid-late 20s and early 40s.

Clearly this initiative is much needed. While much needed, coming on top of the phase in of the 9-year compulsory law, the nationwide initiative to upgrade China's educational system is , however, likely to create a deeper intergenerational divide between the current and recently schooled youth and young adults, who are entering the job market with significantly upgraded skills relative to their immediately older generation. This has all the makings of a deepening and growing income gap between the pre-2005 off-farm job entrants and the recent post-2005 graduates and beyond. ${ }^{15}$

A growing burden on the future workforce. While much of the attention of demographers viewing China's demographic profile is on the growing number of elderly, the change in the age composition of the labor force over the next 20 years is also striking. Not only will the number of newly entering workers continue to decline, while the distribution of their schooling profile increasingly shifts to the right, their share of the overall labor force will decline dramatically. As older workers become increasingly technologically obsolete and underemployed, the new labor force entrants are likely to enjoy rapidly increasing incomes. Many of the new labor force entrants will be competitive on the global labor market commanding incomes consistent with the high-income range of OECD households. The result is likely to be an ever growing income divide between the New Lost Generation and this new globally integrated generation.

One implication may well be that, should it materialize with the force as suggested in this analysis, the Lost Generation becomes an increasing burden on the younger generation now

\footnotetext{
${ }^{15}$ Again, the year 2005 is arbitrary. The generational gap likely lies along a continuum beginning during the period 2000 to 2010 and deepening into the present.
} 
entering China’s more technologically advanced workforce. Moreover, as emphasized in the immediate previous section, a substantial portion of the children of the migrant families are also likely to have suffered from foreshortened, poor-quality schooling, so that like their parents, they too are likely to be disadvantaged as they struggle with a dynamically upgrading labor market. The upshot of this decline in the share of youth and new job entrants in China's workforce is a growing burden for the smaller cohort of new labor force entrants as they are expected to step up to support not only the growing number of retired elderly but also the larger numbers of the offfarm cohort of 1985-2005 - the migrants and their children - that is likely to be increasingly driven to the margin.

\section{Conclusions}

This paper may appear to be making the argument that China's off-farm migrants mistakenly chose to abandon their schooling track prematurely and separate from their families and farming by migrating in pursuit of urban-based industrial jobs. The paper cannot draw that conclusion. Numerous conditions conspired to complicate these decisions. First, we have documented the relative disrepair of China’s rural school system. After graduating from uppermiddle school, even the persevering and talented student may not have been prepared to compete for a so-called "good” job, one with a career ladder that survives into the future. More fundamentally, to remain in a comparatively backward agrarian setting would have guaranteed the lack of access to a good job.

The migration decision was typically made in an uncertain environment. Under the Household Responsibility System in which land security was tenuous under local officials and Party bosses vying for revenue and power, rural youth faced uncertainty about life prospects as a village farmer. On the other hand, the Party may have issued a decree transferring title to the heretofore lessees against the background of a relative rise in the terms of trade for agricultural goods. A key unknown, of course, was China's progress moving up the international technology ladder and the Government's prioritization of measures to facilitate that advance, including the likelihood of the disappearance of a wide swath of jobs suitable for unskilled rural youth. The point of this paper is that China's rural youth faced a set of unpleasant and high-risk choices. The off-farm migration decision may have been the better decision, but it too is likely to be part 
of a larger pattern of persistent income inequality. As a result of chronic under-education, the offarm migration surge, and now a rapidly transforming economy, the generation of migrants that transitioned China to "the world's factory” may increasingly find itself the victim of an increasingly skewed income distribution that is not so much a consequence of the rural-urban inequality of the past as the result of rising inter-generational inequality. Increasingly, China's educational elites - those with elite secondary school and university educations - are likely to reap the benefits enjoyed by China’s transformation to a "knowledge economy," resulting from OECD-like levels of R\&D intensity. Nonetheless the thickening of China's lower income tail resulting from China's New Lost Generation and its children - the households much responsible for transforming China to the "world’s factory" and creating the seeds for its technological dynamism - and the thickening of its upper tail - the beneficiaries of this intergenerational dynamic - will likely result in untold economic, social, and political challenges for the country. 


\section{Bibliography}

Caprice, Leah, (2008), “The Lost Generation of the 17th Chinese Communist Party Politburo,” A Jamestown Foundation Publication: China Brief Volume: 8 Issue: 19

October 7,

2008 http://www.jamestown.org/single/?tx_ttnews\%5Btt_news\%5D=5210\&no_cache=1\#.VxF7 $\underline{\mathrm{xTArI} 2 \mathrm{w}}$

Das, Mitali and Papa N’Diaye, 2013. “Chronicle of a Decline Foretold: Has China Reached the Lewis Turning Point?,” IMF Working Paper Research Department and Asia and Pacific Department, January 2013.

The Economist, "The end of cheap China: What do soaring Chinese wages mean for global manufacturing?” March 10th 2012. http://www.economist.com/node/21549956

, (2014), “Down and Out in Rural China,” August 23, 2014.

Fang, Tony and Lin, Carl, 2013. “Minimum Wages and Employment in China,” IZA Discussion Paper No. 7813 December 2013.

Fei, John and Gus Ranis, 1964. Development of the Labor Surplus Economy, Yale University.

Feng, Shuaizhang, Hu Tingyai, and Moffitt, Robert (2015). “Long Run Trends in Unemployment and Labor Force Participation in China,” NBER Working Paper No. 21460, Issued in August 2015

Fretham, Stephanie J. B., Carlson, Erik S., and Georgieff, Michael K., (2011), “The Role of Iron in Learning and Memory,” Advanced Nutrition, Vol. 2, March 2011, pp. 112-121.

International Labor Organization (ILO), "Labour migration in China and Mongolia,” http://www.ilo.org/beijing/areas-of-work/labour-migration/lang--en/index.htm

Giles, John, Park, Albert, and Wang, Meiyan (2015), “The Great Proletarian Cultural Revolution, Disruptions to Education, and the Returns to Schooling in Urban China,” Discussion Paper No. 8930 March 2015, Institute for the Study of Labor, Bonn.

Han, Jialing (2009), "Education for migrant children in China,” Background paper for the Education for All Global, Monitoring Report 2010

Hannum, Emily (1999). Political Change and the Urban-Rural Gap in Basic Education in China, 1949-1990 Author(s): Source: Comparative Education Review, Vol. 43, No. 2 (May, 1999), pp. $193-211$

Heckman, James, J. (2005), “China’s human capital investment,” China Economic Review Volume 16, Issue 1, Pages 50-70. 
Chang, Hongqin, Dong, Xiao-yuan, and MacPhail, Fiona, “Labor Migration and Time Use Patterns of the Left-behind Children and Elderly in Rural China,” World Development (2011)

Hu, Xiaochu (2012), , “China's Young Rural-to-Urban Migrants: In Search of Fortune, Happiness, and Independence,” Migration Policy Institute, January 4, 2012.

Lewis, Arthur (1954). “Economic Development with Unlimited Supplies of Labour.”Manchester School 22 (May): 139-191.

Liang, Zai and Chen, Yiu Por, (2007). "The educational consequences of migration for children in China,” Social Science Research, Volume 36, Issue 1, March 2007, Pages 28-47

Lewis, Arthur. (1955), The Theory of Economic Growth. London: Allen and Unwin

Lin, Justin Yifu (1987), “The Household Responsibility System Reform in China: A Peasant's Institutional Choice,” American Journal of Agricultural Economics, Vol. 69, No. 2, pp. 410-415.

Lin, Justin Yifu (1989) “Rural Reform and Agricultural Productivity in China,” UCLA Working Paper No. 576, December 1989.

McKinsey and Company (2015). The China Effect on Global Innovation, October, 2015

National Bureau of Statistics, China Statistical Yearbook, China Statistics Press, Beijing, various years.

Naughton, Barry. (2007). The Chinese Economy: Transitions and Growth. Cambridge: MIT Press.

Wall Street Journal, “As China’s Workforce Dwindles, the World Scrambles for Alternatives,” http://www.wsj.com/articles/as-chinas-workforce-dwindles-the-world-scramblesfor-alternatives-1448293942

Yang, Dennis Tao and Li, Yuanfang (2008), Agricultural price reforms in China: Experience from the past three decades. Agroalimentaria 14(27):13-23 • November 2008

Zhang, Linxiu, Huang, Jikun, Rozelle, Scott D., (2002). “Employment, Emerging Labor Markets, and the Role of Education in Rural China,” Agriculture and Resource Economics Working Papers, 04-01-2002, http://escholarship.org/uc/item/1dx4c7bj 
Figure 4

China: Per capita grain output and food availability,

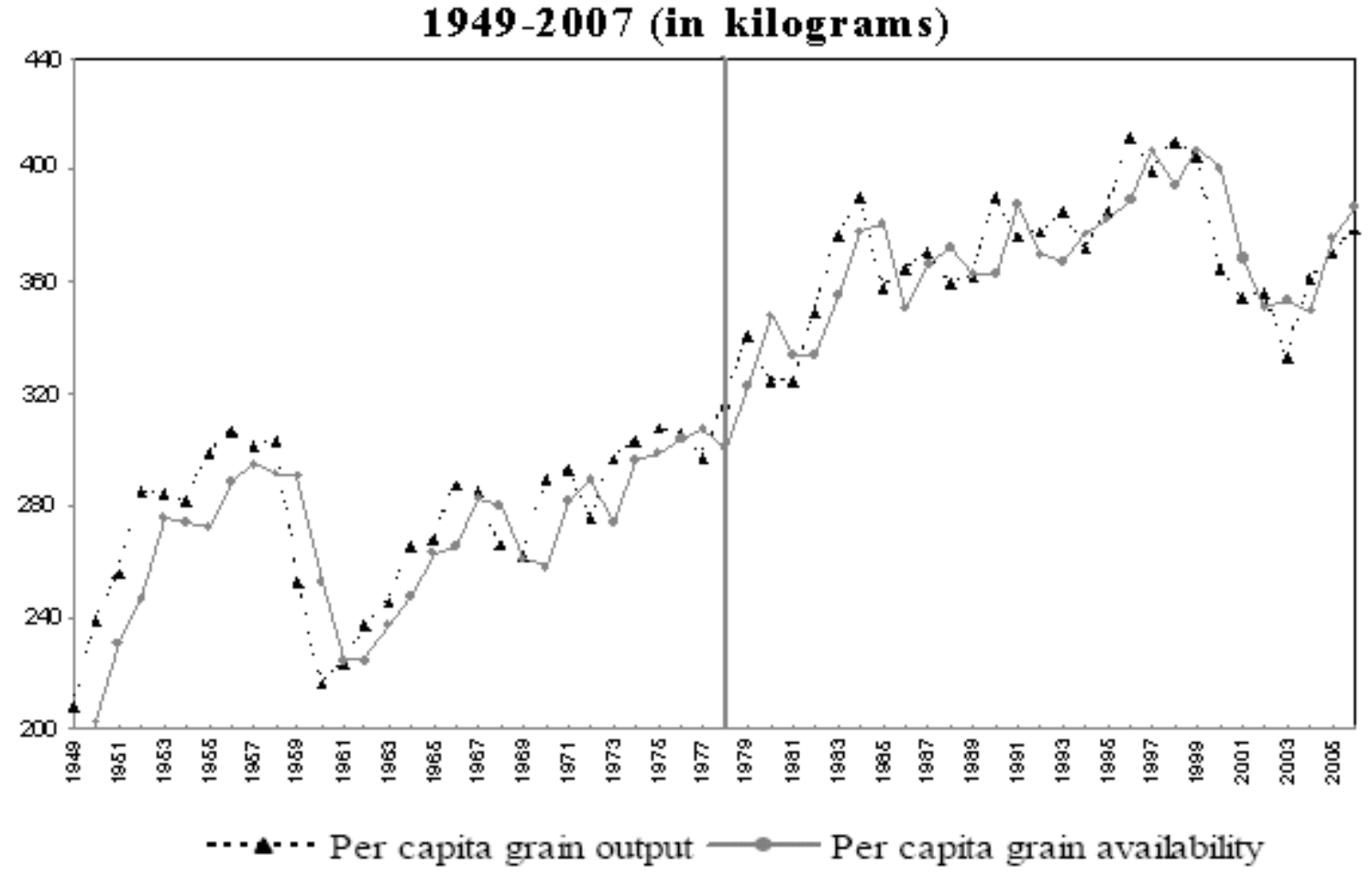

Source: Yang and Li (2008) 


\section{Figure 1}

\section{Chin a: Price indexes of farm input and output, 1951-2006}

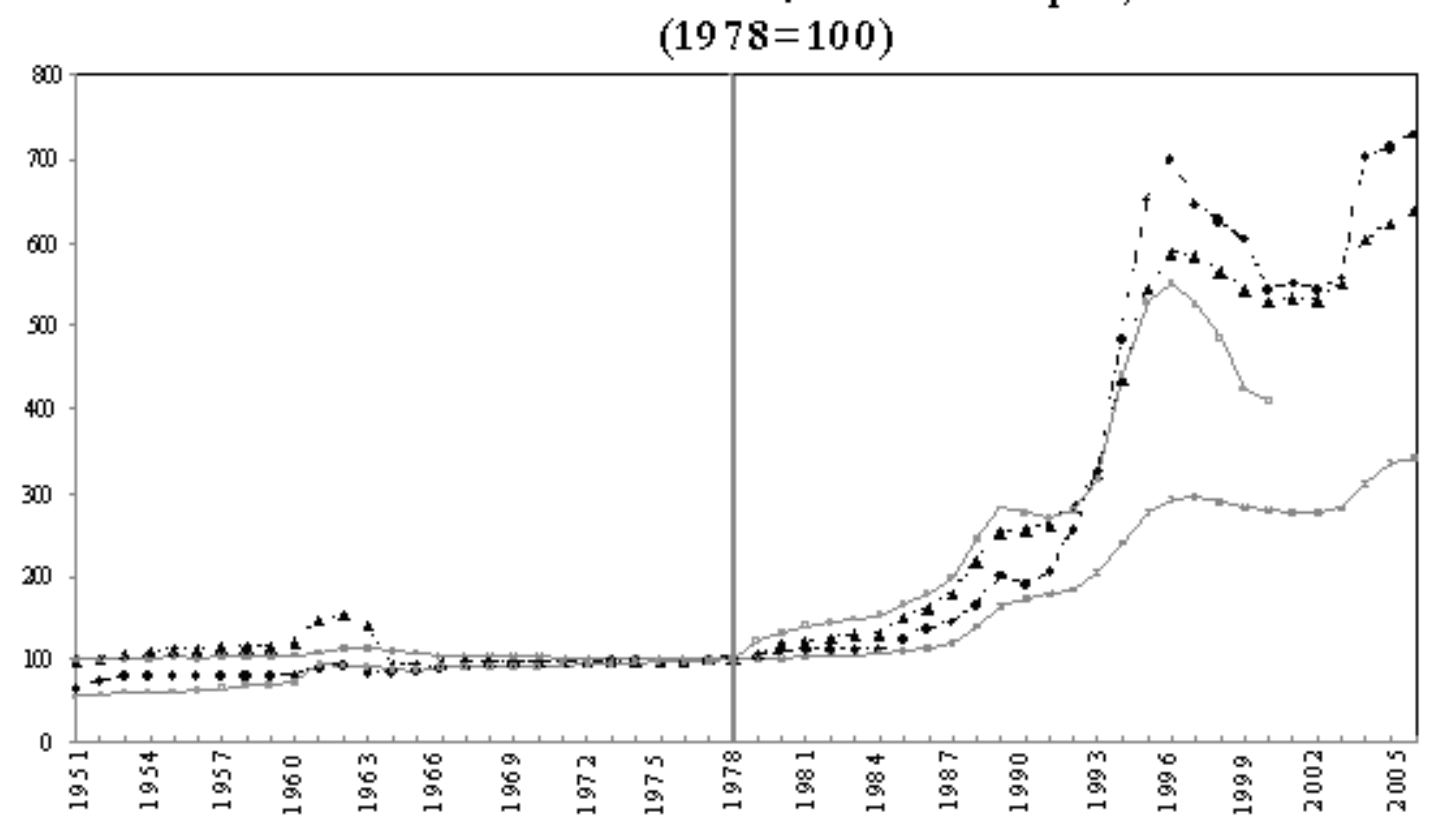

..... Retail price index of food - - - Retail price index of grain

$\longrightarrow$ Procurement price index of farm products $\longrightarrow$ Rural industrial price index

Source: Yang and Li (2008

\begin{tabular}{|l|l|l|l|l|}
\hline \multicolumn{5}{|c|}{ Table 1. Junior Secondary Graduation } \\
\hline & $\begin{array}{l}\text { junior } \\
\text { secondary } \\
\text { graduates }\end{array}$ & $\begin{array}{l}\text { Population } \\
0-14\end{array}$ & $\begin{array}{l}\% \text { of total } \\
\text { population }\end{array}$ & $\begin{array}{l}\text { graduates \% } \\
\text { of age group }\end{array}$ \\
\hline 1982 & 964.7 & 3414.6 & 33.6 & 28.3 \\
\hline 1987 & 1119.3 & 3134.7 & 28.7 & 35.6 \\
\hline 1990 & 1109.1 & 3165.9 & 27.7 & 35.0 \\
\hline 1995 & 1227.4 & 3221.8 & 26.6 & 38.1 \\
\hline 2000 & 1607.1 & 2901.2 & 22.9 & 55.3 \\
\hline 2005 & 2106.5 & 2794.7 & 21.5 & 75.4 \\
\hline 2010 & 1748.6 & 2225.9 & 16.6 & 76.6 \\
\hline Source: NBS (2012) & \multicolumn{4}{l}{} \\
\hline
\end{tabular}




\begin{tabular}{|l|l|l|l|l|l|l|}
\hline \multicolumn{7}{|c|}{ Table 2, School enrollments } \\
\hline & $\begin{array}{l}\text { Primary } \\
\text { enrollments }\end{array}$ & $\begin{array}{l}\text { Primary } \\
\text { graduates }\end{array}$ & $\begin{array}{l}\text { Junior } \\
\text { secondary } \\
\text { enrollments }\end{array}$ & $\begin{array}{l}\text { No. graduating } \\
\text { 3 years later }\end{array}$ & $\begin{array}{l}\% \\
\text { graduating }\end{array}$ \\
\hline 1978 & 3315.4 & 2287.9 & 2006.0 & & $964.8(1980)$ & \\
\hline 1980 & 2943.3 & 2053.3 & 1557.6 & & $1007.2(1985)$ & \\
\hline 1985 & 2298.2 & 1999.4 & 1349.9 & 67.4 & 1157.2 & $85.4(57.6)$ \\
\hline 1986 & & 2016.1 & 1386.6 & 68.7 & 1134.3 & $81.8(56.2)$ \\
\hline 1987 & & 2043.0 & 1394.3 & 68.2 & 1109.1 & $80.0(54.3)$ \\
\hline 1988 & & 1930.3 & 1340.5 & 69.4 & 1085.5 & $81.0(56.2)$ \\
\hline 1989 & & 1857.1 & 1309.4 & 70.5 & 1102.3 & $84.2(59.4)$ \\
\hline 1990 & 2064.0 & 1863.1 & 1369.9 & 73.5 & 1134.2 & $82.8(63.7)$ \\
\hline 1995 & 2531.8 & 1961.5 & 1752.3 & 89.3 & 1580.2 & $90.2(80.5)$ \\
\hline 2000 & 1946.5 & 2419.2 & 2263.3 & 93.6 & 1995.6 & $88.2(82.5)$ \\
\hline 2005 & 1671.7 & 2019.5 & 1976.5 & 97.9 & 1862.9 & $94.2(92.3)$ \\
\hline 2010 & 1691.7 & 1739.6 & 1715.5 & 98.6 & 1561.5 & $91.0(89.7)$ \\
\hline Source: NBS (2012) & & & & \\
\hline
\end{tabular}

Table 8-2: Educational Attainment of Population, 15 and Above

\begin{tabular}{lcccc}
\hline & 1982 & 1990 & 1995 & 2000 \\
\hline Illiterate, Semi-literate & $34.5 \%$ & $18.5 \%$ & $13.6 \%$ & $9.1 \%$ \\
Elementary & $30.8 \%$ & $43.2 \%$ & $43.6 \%$ & $71.7 \%$ \\
Lower Middle & $23.8 \%$ & $27.2 \%$ & $31.0 \%$ & \\
Upper Middle & $10.0 \%$ & $9.4 \%$ & $9.4 \%$ & $14.5 \%$ \\
College & $0.9 \%$ & $1.7 \%$ & $2.3 \%$ & $4.7 \%$ \\
\hline
\end{tabular}

Source: 1982 Census Summary Volume, p. 360

China Population Statistics Yearbook 1996, pp. 5, $154-55$.

2001 Almanac of China's Population, p. 147; 2002 Statistical Yearbook, p. 110.

2000 are preliminary calculations.

Source: Naughton (2007) 


\section{Where Do People Fail To Attain A High School Qualification?}

$\%$ of 25-34 year-olds with an education level below upper secondary in selected countries*

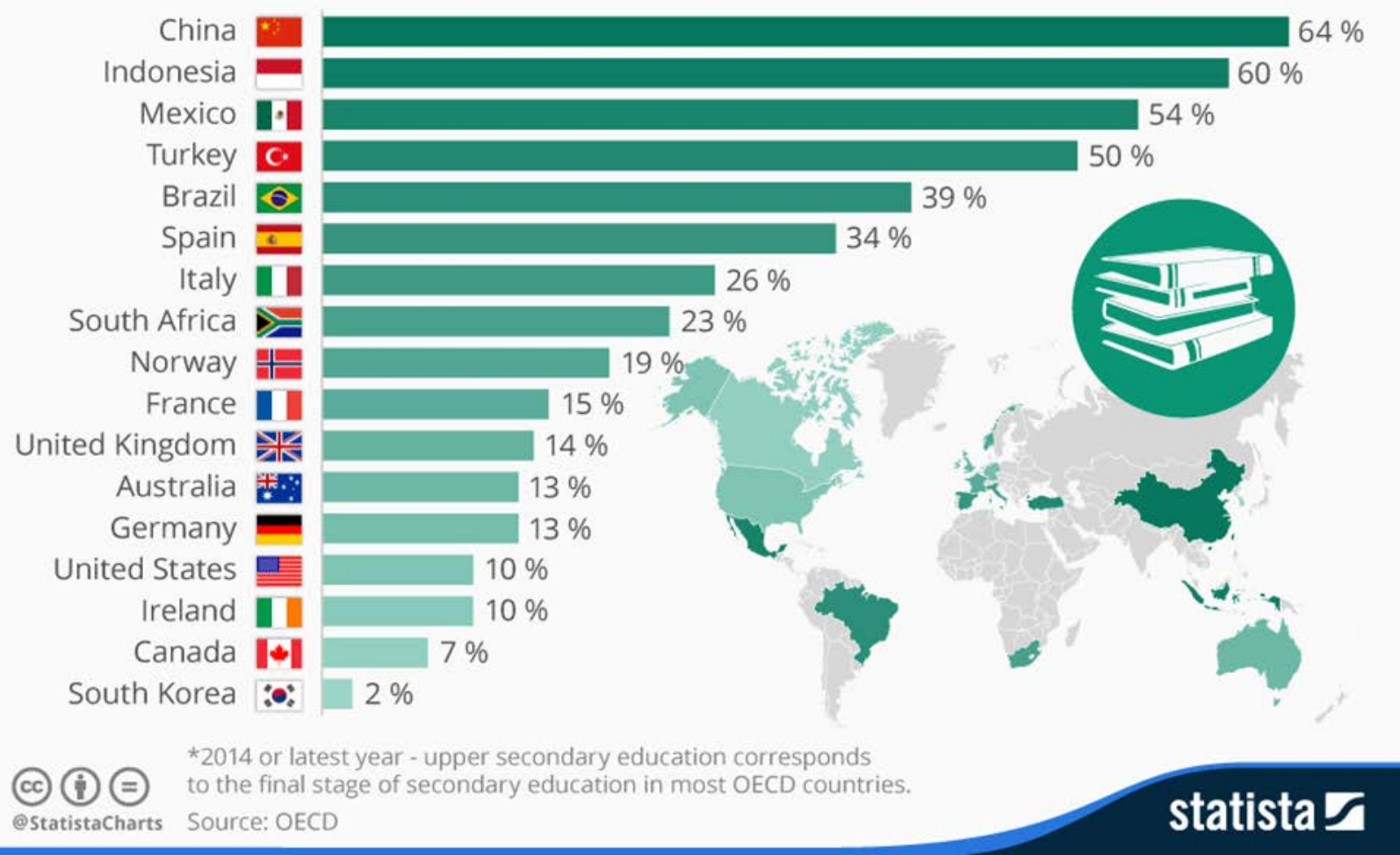

Table 2. Level of education for rural population between 1988-1996

\begin{tabular}{lccc}
\hline Education level & $\mathbf{1 9 8 8}$ & $\mathbf{1 9 9 2}$ & $\mathbf{1 9 9 6}$ \\
\hline \multirow{2}{*}{ Total } & 5.33 & 6.10 & 5.20 \\
& $(3.78)$ & $(3.61)$ & $(3.69)$ \\
Male & 6.51 & 7.30 & 6.64 \\
& $(3.49)$ & $(3.12)$ & $(3.04)$ \\
Female & 3.92 & 4.72 & 3.63 \\
& $(3.63)$ & $(3.64)$ & $(3.72)$ \\
\hline
\end{tabular}

Source: Author's survey.

Note: Figures in brackets are the standard deviations.

Zhang, Rozelle et al (2002) 
FIGURE 3.6 Distribution of educational readiness test scores for children at age 4-5, Urban (top panel) and rural (bottom panel) China

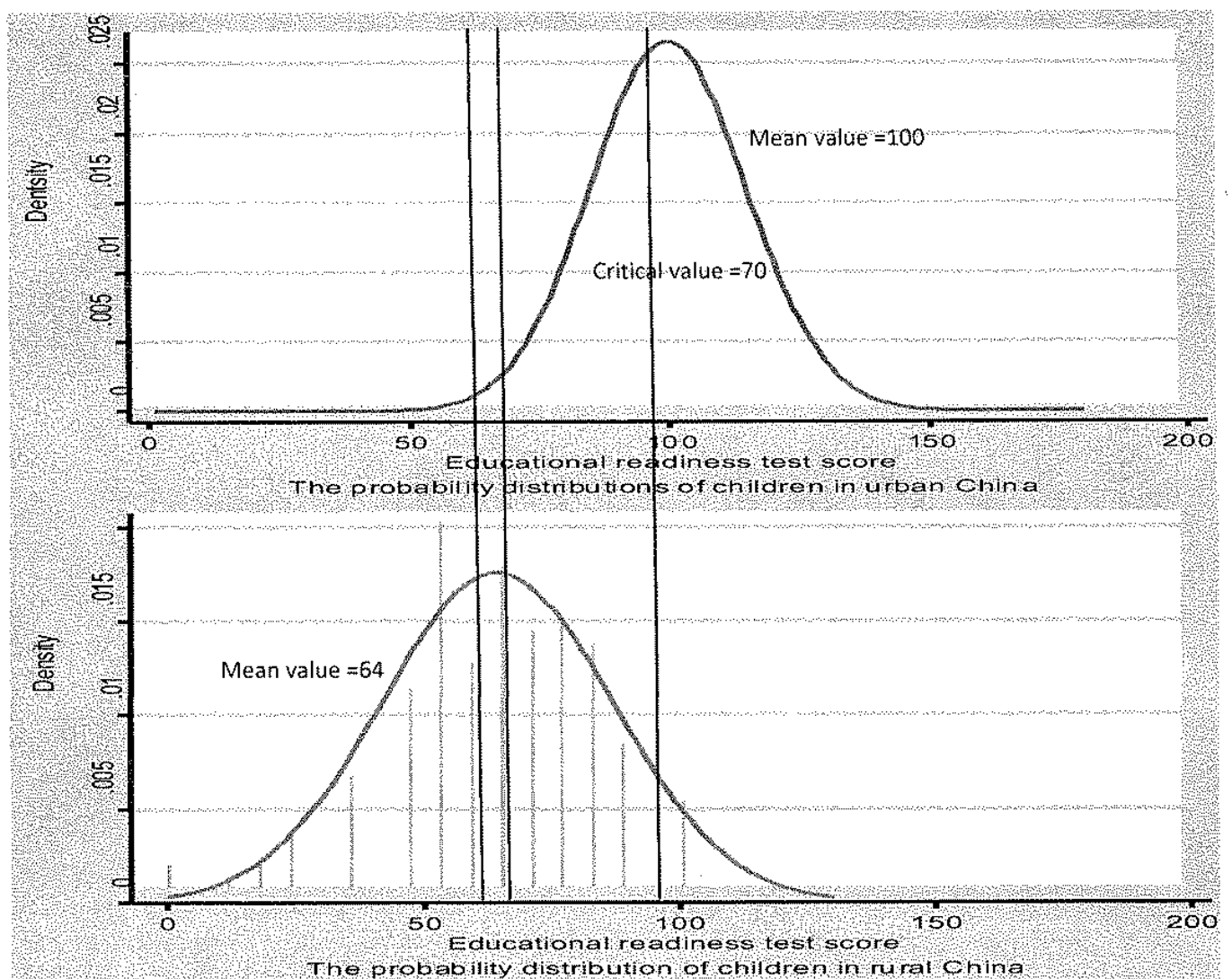

Sources: Data in top panel, Ou, 2007. Data in bottom panel, Rozelle (2011) for Gansu, Henan and Shaanxi.

FIGURE 3.2 Anemia prevalence in rural children under 5 years of age, in months $(\%)$
Figure 3.3 Anemia prevalence in children under 5 years of age in rural poor areas, in months $(\%)^{33}$

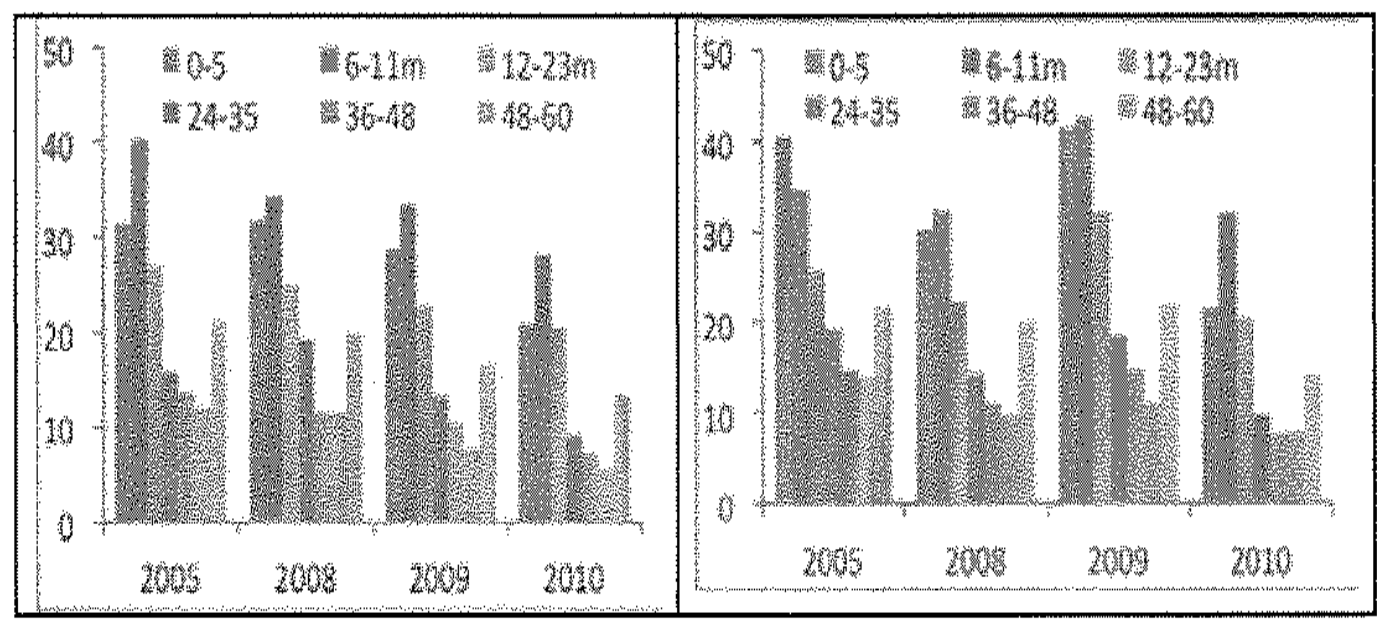

Source: CHNS various years.

Source: CHNS, various years. 


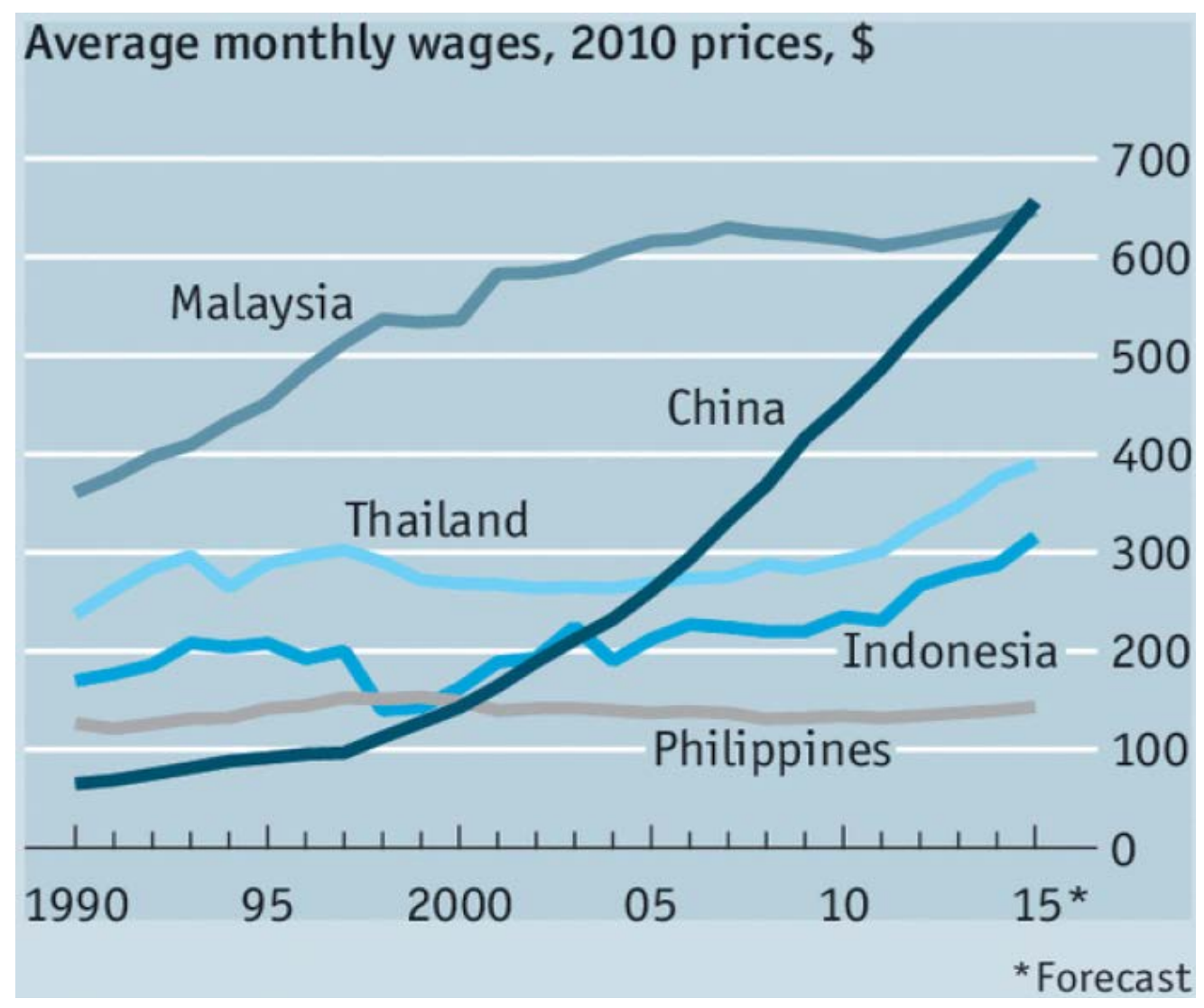

Source: The Economist, “The Tightening Grip,” March 14,

2015, http://www.economist.com/news/briefing/21646180-rising-chinese-wages-will-onlystrengthen-asias-hold-manufacturing-tightening-grip 


\title{
China's New Lost Generation: The Casualty of China's Economic Transformation
}

\author{
Gary H. Jefferson \\ jefferson@brandeis.edu
}

July 24, 2016

Forthcoming: Journal of Chinese Economic and Business Studies

\begin{abstract}
China's surge into global middle-income status over the space of three decades has been spectacular. However, a potentially large and burdensome cost has been imposed on a generation of adolescents and young adults who abandoned the countryside, and with it access to basic education, in order to seek the anticipated advantages of jobs in the country's burgeoning urban-industrial sector. This large swath of off-farm migrants transformed China. It propelled China to the status of the "world's factory" and created the scale and accumulated learning-bydoing enabling China's transition to a "knowledge economy” that no longer depends on the labor of China's new "Lost Generation.” As the Lost Generation and its left-behind children, who suffer from a chronic lack of schooling, thicken the lower tail of China's income distribution, it may be the rising, prosperous urban middle class that ultimately incurs the social, economic, and political challenges associated with China's generation of off-farm migrant households once essential for launching China’s economic ascent.
\end{abstract}

JEL classifications: J21, J24, J31, O15, O33

The author deeply appreciates the editorial suggestions offered by Andrea Oseas. 


\section{Introduction}

Since 1980, China has dramatically transformed its relatively backward and inefficient economy into an immense industrial economic system with the world's largest industrial workforce producing the most industrial output and generating the largest volume of exports in the world. A major source of this transformation has been the huge exit of workers from agriculture to industry. Zhang, Huang, and Rozelle (2002, p. 38) start their paper with the following summary:

The massive flow of labor into the off-farm sector has brought new prosperity to millions of rural households during China's economic reform era. The proportion of the rural labor force that has entered the labor force rose from around 22\% in 1988 to 34\% in 1995 (Rozelle et al., 1999). By 2000, nearly 200 million people (or about $40 \%$ of laborers) held off-farm jobs. The rise in wage earnings and income from self-employed activities has created most of the increase in rural incomes in the late 1980s and 1990s (Parrish, Zhe, and Li, 1995; Rozelle, 1995).

The authors' summary account of the surge in off-farm employment and living standards during the 1980s and 1990s is impressive. By any measure, hundreds of millions of Chinese residents graduated from poverty during this period. Most likely, in terms of the sheer number affected and the extent of improvement, the number far exceeds any other two-decade economic transformation in human history. Ironically, the achievement described by Zhang et al. above also created the likelihood of challenging conditions that are now emerging and will probably persist for decades to come for tens of millions of the off-farm industry migrants.

In August 1966, approximately 20 years before the beginning of the surge in off-farm migration celebrated by Zhang et al. (2002), Mao Zedong launched the Cultural Revolution by sending young Red Guard youth from China’s cities to the countryside. Two years later the Party broadened the urban-rural migration by issuing an order to every urban household: at least one of their teenage children needed to leave the city indefinitely to contribute to rural farm work. The tumult resulting from this political command, requiring that the privileged urban "intellectual" youth learn from farmers and workers, persisted from 1968 until the mid-1970s.

According to Chinese sources, across the country, as many as 17 million "intellectual youths" packed their bags and moved to some of the most remote parts of China, where they 
transformed from urban-dwelling students to farmers. ${ }^{1}$ With many schools in China's cities ranging from primary schools to universities having been shut down thus displacing China's urban youth from its formal educational mission, ${ }^{2}$ this urban generation of the late 1960s and early 1970s has come to be known as China’s Lost Generation. The contrasts with China's offfarm migrants of the late 1980s through the 1990s are stark: the post-reform migrations being purely voluntary rural-urban relocations in service to China’s capitalist transformation; contrasted with the politically-enforced, urban-rural, anti-capitalist disruption of the earlier Cultural Revolution. Nonetheless, the large-scale displacement of the migrants from the classroom during the early decades of China's Economic Reform have likely amounted to the loss of hundreds of millions of school years, which, associated with the increasingly dead-end nature of largely low-skill occupations, may be setting the stage for China's New Lost Generation.

Ironically, in the process of establishing China as the "world's factory" China's off-farm migrants have created four conditions that are severely dimming their prospects for their own longer-run household prosperity; these are:

1. terminating their education so as to limit their future employability;

2. substantially diminishing the supply of China's surplus labor, moving China toward its Lewis Turning Point, thereby putting upward wage pressure on China’s low-wage employers.

3. creating "the world's most extensive manufacturing ecosystem" that has in turn enabled “...continuous innovations in production processes that reduce costs and improve quality” (McKinsey 2015, p. 7); that is, creating the capacity for Chinese industry to move up the technology ladder.

4. as a result of \#2 and \#3, severely reducing the supply of semi-skilled, low-wage jobs upon which China's first generation of off-farm migrants have largely depended so as to render larger portions of this population substantially under employed and unemployable.

\footnotetext{
${ }^{1}$ CNN World (Tracy You), "China's 'lost generation' recall hardships of the Cultural Revolution," http://www.cnn.com/2012/10/24/world/asia/china-lost-generation/

${ }^{2}$ During the period 1966-1970, China's Ministry of Education suspended its reporting of the breakdown between urban and rural school enrollments. When the reporting resumed in 1971, the proportion of middle and high school students reported as rural enrollments rose from just 31.9\% in 1965 to $70.9 \%$ in 1971. (Hannum, 1999, Table 1).
} 
Broadly defined, the early generation of off-farm workers in their early adolescent and adult years had their employment opportunities bracketed by the proliferation of low-wage, lowskill jobs associated with China's initial rural industrialization during the 1980s followed by the surge of foreign direct investment beginning in the mid-1990s and peaking shortly after China's ascension to the WTO. The exit of tens of millions of workers from the farm sector substantially diminished the supply of rural surplus labor, thereby effectively moving China toward the socalled Lewis Turning Point. The consequent emergence of reported labor shortages has occasioned a mix of alarm and satisfaction that these shortages have begun to force a general restructuring of the Chinese economy. This analysis generally focuses on the period 20-year period from 1985 to 2005 as that during which China's generation of rural youth, referred to in this paper as the New Lost Generation, became most at risk for becoming entrapped in the dynamic of dropping out of school and migrating off-farm for destinations that have generally led to transient, dead-end employment.

The following sections document and analyze this phenomenon of China New Lost Generation. Section 2 relates the theoretical framework for understanding the mass migration of China's excess supply of rural labor to the actual circumstances of the 1985-2005 period. Section 3 examines the educational profile and schooling choices relating to China's rural sector. Section 4 analyzes the supply of surplus labor, including the Lewis Turning Point. Section 5 identifies the drivers of China's industrial transformation during this period. Section 6 analyzes the impact China's off-farm migration phenomenon on the children of the migrants. Section 7 draws conclusions from the analysis.

\section{The theoretical setting: the 2-sector model}

This economic logic of China's industrial transformation is captured in the two-sector economic growth model of Lewis (1955) and its more formal representation and extension by Fei and Ranis (1964). In this model, the rural agricultural sector is populated by substantial quantities of excess labor, forcing the marginal product of farm labor to hover in the range of the subsistence wage or even falling to near zero. Life is sustained through the establishment of formal and informal collective village or family arrangements that distribute income and consumption goods to enable subsistence levels of living standards. Coincident with this rural 
condition is an emerging industrial sector in which investment and technology transfer results in the robust growth of labor demand and shifting out of labor's marginal product schedule. As the demand for labor rises, wages in the industrial sector rise above the subsistence wages that had been paid to the diminishing numbers of underemployed surplus rural workers. As long as the continuing rise in industrial wages is sufficient to draw workers with the requisite skill levels from their rural settings, the growth of the urban industrial sector will motivate low-wage farm workers to abandon their farm work and migrate to the urban industrial sector to secure more lucrative employment.

This Lewis and Fed-Ranis two-sector has direct relevance to China. The Household Responsibility System (HRS) spread rapidly over the Chinese countryside during 1980-1983. Full official recognition of the HRS as universally acceptable was given in late 1981; at that time, 45.1\% of production teams in China had already switched to this system. By the end of 1983, 94.2\% of households in China's rural areas had adopted it. ${ }^{3}$ It is well documented that the adoption of the HRS led to dramatic increases in China's agricultural productivity and rural living standards. Poverty rates fell dramatically. While gross agricultural output increased by nearly 90\% (NBS, 2008, p. 448), rural agricultural employment expanded by just 6.9\% (NBS, 2008, p. 114). Although irrigated area declined by 0.5\% (NBS, 2008, p. 451), over this 3-year period, the number of small tractors more than doubled (NBS, 2008, p. 450) while the consumption of chemical fertilizer and electricity, both increased by approximately 50\% (NBS, 2008, p. 451). As a result of more efficient crop mixes and improved labor allocation and incentives, as well as the growth of complementary inputs, labor productivity in agriculture rose dramatically, nearly doubling.

One curious feature of the surge in China's measured agricultural productivity stands out. During 1980-84 when the household responsibility system (HRS) unfolded, labor productivity growth in the agricultural sector rose robustly at approximately 8\% per year. Notwithstanding the fact that wholesale decollectivization did not begin until 1980, we see that during 1977-79, prior to the implementation of the HRS, China also experienced a surge in agricultural productivity as crop output rose by $17 \%$ during this 2-year period, while reported labor rose by only slightly more than one percent. This surge, beginning in 1977-78 and continuing until 1985 is shown in Figure 4 (Yang and Li, 2008).

\footnotetext{
${ }^{3} \operatorname{Lin}(1987)$.
} 
According to Lin (1989), the key change in this time was the substantial increase in stateabove quota contract prices, an increase of more than $40 \%$ relative to 1978 versus less than a $3 \%$ increase since 1970. These changes in crop prices, both state procured and market prices appear in Yang and Li (2008), Figure 1.

What is not highlighted is the concurrent dramatic decline in school enrollments that corresponded to the robust rise in crop prices, state procurement and otherwise. During 1978-85, official statistics show the number students graduating from primary school declining from 22.88 million in 1978 to 20.53 million in 1980 and 20.00 million in 1985; over the same period, the number of new student enrollments in junior secondary school declined more precipitously from 20.07 million in 1978 to 15.51 million in 1980 and 13.49 million in 1985. (NBS, 2012, Table 20-7 and 20-07, pp. 752-753). The 1985 figures represent the smallest cohorts in the 1980s, until 1988 when, most likely as a result of the One-Child Policy, the primary school population begins to drop off.

These figures are of interest in this context principally because they may be a harbinger of the responsiveness of school enrollments to economic incentives, first during the post-1977 period as procurement prices and institutional reform combined as powerful incentives to mobilize household labor on behalf of agricultural production, and then following 1985 as rural and urban industrialization surged to reallocate farm labor to factory employment. The decline in school enrollments beginning as early as 1978 may well have reflected the responsiveness of adolescent and young adult labor to employment incentives across China's transforming economy.

\section{China's education profile}

In making their migration decision, China’s rural youth generally confronted a choice between a life engaged with work in agriculture, possibly mixed with secondary (industry) or tertiary (service) sector employment and relocation to a job in industry or construction. During the late 1980s into the 1990s, this rural cohort generally completed primary school, became literate, but did not complete lower middle school and only infrequently enrolled in upper-middle school. 
In an extensive interview of migrants within Guangdong province, the survey team in their report Primary Migration Motivation: "Why I left the Village" (Hu, 2012) asked the "new generation" migrants to explain their decisions to leave the farm-education setting for urban employment. They summarized the response as follows:

In the interviews, we asked each of the migrant workers the question of why they first decided to migrate out of the village. Instead of having been pushed by harsh economic times in the village, it turns out many were pulled by opportunity and the excitement of city life. Interestingly, being tired of school was one of the most frequent answers to the primary migration motivation question, surpassing economic reasons. Many of our interviewees expressed little interest in school and did not complete their compulsory nine years of education before migrating. A secondary reason emerged, however, for not finishing school: the inability or unwillingness to pay for schooling when job opportunities in cities became available. After dropping out, the Chinese school enrollment structure all but precludes youth from going back to school and continuing their education where they left off.

According to the report, the National Bureau of Statistics report found that the first migrating age of migrants born between 1980 and 1990 is 21.1, while the age for those who were born after 1990 is 17.2 - considerably younger. Having migrated after limited years of schooling, migrants face high pressure from work, low satisfaction in terms of their wages, unsure selfidentification (villager or citizen), and an overall lack of happiness.” (Hu, 2012).

First, we look at the nationwide distribution of school enrollments and achievement. While not a precise measure, Table 1 attempts to measure the proportion of young children in the 0-14 age bracket that graduate from lower secondary school, i.e.. typically with 9-years of schooling. The figures show a graduation rate of less than $30 \%$ in 1982, rising to the range of $35 \%$ to less than $40 \%$ during the period $1987-1995$. Thereafter the rates rise rapidly to $55 \%$ in 2000 and three-quarters in 2005 and 2010. In order to understand the implications of these figures for China's rural-urban divide, it helps to understand that in 1986 the Chinese government promulgated a regulation that required 9-years of compulsory schooling. However, this requirement was to be phased in. According to Hannum (1999, pp. 200-201), “Cities and economically developed areas in coastal provinces and some parts of the interior where onequarter of the population resides were expected to universalize 9-years of compulsory education by 1990. Elsewhere, as Hannum describes, semi-developed areas representing about one-half of the population were expected to satisfy the regulation by 1995, whereas the underdeveloped 
regions accounting for the remaining one-quarter of the population were expected to achieve universal elementary education with a target for universalizing lower secondary education. Table 1 suggests that there was little change by 1990 and some marginal improvement by 1995 but notable gains only materialized toward 2000 with substantial gains showing in 2005, nearly 20 years after the adoption of the Compulsory Education Law.

The statistics in Naughton's Table 8.2 for China’s population over 15-years of age are largely consistent with this account. They show stagnant shares of the population gaining only an elementary school education from 1990 to 1995, with little gain in the proportion of junior secondary school graduates. Also, over the period 1982-1995, the share with upper-middle school and college degrees only grew from 10.2 to $11.7 \%$. Note that beginning in 2000 , Naughton's table shows the beginning of substantial gains at the upper end of schooling as the proportion with upper-middle school or college degrees rose from $11.7 \%$ in 1995 to $19.2 \%$ in 2000.

According to Figure 2, the Statistical/OECD chart, by 2014, the proportion of 25-34 year olds without a high school degree in China stood at 64\%, indicating that the proportion with a high school education stood at 36\%. Given the focus on 25-34 year-old students, this result indicates that during the 2000-2010 period, when this cohort was of high school age, a relatively small proportion China's youth were achieving high school educations. The fact that the compulsory education requirement appears to have only been effectively in force in 2000 for the coastal population and the more advanced interior urban areas, suggests that a very small proportion of China's rural population could be counted among the young adult population with at least a high-school degree.

As indicated above, the overall national enrollment figures seriously obscure the disparity between rural and urban enrollment profiles. According to The Economist (Aug 23, 2014), in 1990, when off-farm migration was a well-established feature of China’s industrializing landscape, only $7 \%$ of rural students entered upper middle-school. Explaining this dismal statistic, The Economist elaborated:

"Some quit school because of the cost, in contrast to many other countries, the upper years charge for tuition. Senior middle-schools are often far away from villages, so students have to board. Including the cost of books, the bill for three years can easily amount to thousands of dollars - more than a year's income for poorer rural families. About half fail the test to get into senior middle-school. Others leave because they can 
get what they consider a decent job. Wages for low-skilled work have increased greatly in recent years...."

Table 2, Figure 3.6 and Figures 3.2 and Figure 3.3 explicitly document the disparity between educational outcomes in China's rural and urban areas. In Table 2, Zhang, Rozelle et al. (2002) report their results for the number of years of schooling obtained by males and females for the years 1988, 1992, and 1996. Despite the bump in 1992, these show no improvement from 1988 to 1996, during which the average male student barely received more than 6 years of primary education, whereas the females come up substantially short of closing in on a primary school degree.

As shown in Figure 3.6, Ou (2005) and Rozelle (2011) show how China’s deep ruralurban educational divide has its origins in early childhood. This diagram compares the “educational readiness” of China’s children aged 4-5 in urban areas. The authors, Ou (2007) and Rozelle (2011) report that the lower “critical threshold” for preparation to succeed in primary schooling and beyond is 70. Ou (2007) shows a mean $=100$ for the distribution of urban readiness; based on survey work in Gansu Henan, and Shaanxi, Rozelle (2011) reports that even the mean of rural child educational readiness lies below the basic readiness threshold.

One explanation for this poor rural showing is shown in Figures 3.2 and 3.3. These show the incidence of anemia in rural children under 5 years (Fig. 3.2). ${ }^{4}$ Because the symptoms of anemia entail serious impediments to normal physical development and learning readiness, the incidence of anemia is likely to be highly correlated with educational readiness. As shown in this figure, in 2005, in rural areas, $40 \%$ of the children under one-year old exhibited the symptoms of anemia. In the rural poor areas, as late as 2009, this figure exceeded $40 \%$.

One of the research objectives of Zhang, Huang, and Rozelle (2002) is to “...to examine if education in different time periods - the late 1980s, the early-1990s and the mid-1990s - can be associated with increasing access to off-farm jobs.” The author's hypothesis is that if rural labor markets are improving, the survey data should show that access to off-farm work improves and wages rise with education; also, the relationship should become stronger over time. The study by Zhang, Huang, and Rozelle clearly shows that education affects the ability of the

\footnotetext{
4 “Early life ID affects at least 3 major neurobehavioral domains, including speed of processing, affect, and learning and memory, the latter being particularly prominent. The learning and memory deficits occur while the infants are iron deficient and persist despite iron repletion. "Stephanie J. B. Fretham, Erik S. Carlson, and Michael K. Georgieff, "The role of iron in learning and memory," http://advances.nutrition.org/content/2/2/112.full
} 
household to take advantage of off-farm employment opportunities in rural China and that this tendency is rising over time. In all three years of their surveys -1988, 1992, and 1996 - individuals with a middle school education and above have higher off-farm participation rates (Table 3, rows 1 and 2). Perhaps more importantly, the difference between those with less and those with more education is expanding sharply over time. In 1988 and 1992 the off-farm participation rates of those with middle school or above exceeded that of those with less education by around 50 percent. By 1996, however, the youth with middle-school degrees had off-far participation rates that were more than twice those without middle-school degrees. The relationship between education and wages also has changed during the reform period (Table 3, rows 5 to 10). In the late 1980s, wages for middle school graduates and above were actually below those who had only graduated from elementary school education (in the middle-aged and old-aged categories). By the mid-1990s, however, a sharp reversal had occurred. For all age groups, those with a middle school education and above earned more on a per day basis than those with only an elementary education. Across all age categories, the real wage rose more than 10 percent faster annually between 1988 and 1996 for those with higher education levels when compared to those with only elementary schooling.

One report, however, a National Bureau of Statistics report cited by Hu (2012) finds changes in migration age structure that are not entirely consistent with Zhang et al.'s result. That is, the report found that for migrants born between 1980 and 1990, the first migrating age was 21.1, while the age for those who were born after 1990 was 17.2 - considerably younger. However, one way of reconciling the finding of more rural adolescents extending their schooling into middle school is that unlike the initial cohort, almost immediately upon finishing their schooling, the more recent youths are departing for their off-farm work destinations.

These results indicate that China's rural labor market has become more efficient during the period analyzed in this paper - a more efficient machine for matching school dropouts and graduates with jobs that match the education, skill, and wage profile of migrants and industrial employment. The results indicate that while initially, through their labor-market encounters, China's rural youth faced a negligible incentive to remain in school, so that they might acquire the skills to qualify for a higher wage, increasingly secondary school graduates were rewarded for extending their education in relation to their counterparts who chose to select off-farm labor 
after graduating from primary school. This condition may help to explain the rise in seniorsecondary school graduation rates in 1996, which had been falling steadily from 1987 to 1995.

\section{Supply of surplus labor: The Lewis Turning Point}

Section 2 sets the theoretical framework for understanding the strategic calculus of the Lost Generation in deciding to migrate for off-farm employment and therefore forgo, at least for the immediate future, schooling and participation in China's farm economy. According to national statistics, by the end of 2009, China had a total of 229.8 million rural migrant workers. Among them, 145.3 million rural migrant workers worked outside of their hometowns for a period over six months and almost 84.5 million worked within their hometowns for a period over six months. Around $70 \%$ of migrant workers are employed in China's eastern areas with two thirds of them working in large or medium cities and half of them moving between different provinces. Approximately $60 \%$ of migrant workers are mainly concentrated in manufacturing and construction. ${ }^{5}$

China's labor shortage has arisen not only as a result of the extensive hollowing out the large pool of surplus labor via off-farm migration, the growing shortage is becoming yet more severe with secular declines in the rates of population growth and new labor force entry. The decline in labor force growth is the culmination of the second and third generation of families that have formed under initiatives of the Chinese government to depress fertility. These began with the government's campaign in the 1970s to encourage "later marriage, longer intervals between children, and fewer children" using a variety of birth control means. This then culminated with the One-Child Policy that was formally adopted in the 1980s. The population effects of such campaigns do not happen immediately within the space of a single cohort. Their impacts occur through two channels. The first, which may materialize in the near term, is a reduction in women's total fertility rates, say from 3 to 1.5. The longer-term effect is the sheer reduction in the number of child-bearing women, an effect that cascades from generation to generation, so that two to three generations into the fertility reduction campaign, there may be

\footnotetext{
${ }^{5}$ International Labor Organization, "Labor migration in China and Mongolia," http://www.ilo.org/beijing/areas-ofwork/labour-migration/lang--en/index.htm
} 
only half as many women of child-bearing age, each bearing fewer children than the larger cohort of their grandparents.

We see this decline most starkly in Table I, which shows the number and proportion of the population represented by China's youth in the range of 0-14 years old. In 1982, the 14 and under population consisted of 341.46 million persons, representing one-third of China's total population. By 2000, the 0-14 population had declined to 290.12 million down to $22.9 \%$ of the population. During 2000 to 2010, the decline accelerated by 57.5 million to 222.59 million, $16.6 \%$ of the population accounting for just one half of the total population that it had accounted for in 1982.

As a result of the confluence of these inter-related factors - the precipitous decline in China's young population and depletion of surplus labor in the farm population - China's working age population has reached an historical peak and has begun a rather dramatic secular decline. While Das and N'Diaye (2013) anticipate that the reallocation of surplus labor from the rural sector will drive the Chinese economy to the Lewis Turning Point during 2020-2025, it is not clear that they have fully taken into account the overall decline in the growth of population and the labor force. In any event, Chinese manufacturers appear already to be taking the technology upgrading required to address the growing labor shortage and attendant surge in industrial wages. ${ }^{6}$

5. Industrial development and technology upgrading in Chinese industry

Between 1980 and 2013, total employment in China has grown from 423.6 million to 769.8 million. Over this period, industry's employment share grew from $18.2 \%$ to $30.1 \%$. Within the industrial sector, the composition of enterprise ownership and employment changed dramatically. Industry productivity growth and technology advancement have been robust throughout the reform program, with China increasingly transforming from an imitation economy to an innovation economy.

Following the beginning of economic reforms, China's off-farm industrial landscape initially began its transformation with the township and village enterprises, whose ownership

\footnotetext{
${ }^{6}$ For a summary of recent research on the subject, see The Economist, "China Approaching the Turning Point," January 31, 2013, http://www.economist.com/blogs/freeexchange/2013/01/growth-and-china
} 
converted from communes and collectives of the socialist period to factories that proliferated and expanded rapidly throughout the countryside. From 1980 to 1996, TVE employment rose from 30 million, representing 9.4\% of total rural employment, to 135.1 million, having grown to $27.6 \%$ of China’s total rural employment. (NBS, 2014) After peaking in 1996, TVE employment trailed off as TVEs were forced to restructure substantially. With increased market integration and competition, official discrimination against TVEs, and official preference for foreign-owned enterprises, TVEs lost their competitive position (Naughton, 2007).

During 1995 to 2005, overall industrial employment stalled, growing by just 11.3\% over the decade compared with having more than doubled from 1980-1995. Later, during the subsequent decade, from 2005-2013, industrial employment grew by over one-third. (NBS, 2014) The 1995-2005 slowdown most likely reflected the episodes of "xiagang” and "jueda fangxiao," the privatization of thousands of SOEs accompanied by the "furlough" of tens of millions of workers in the state sector. Based on Ministry of Labour and Social Security (MOLSS) figures, 21 million workers were laid-off from SOEs between1994 and 2005; when laid off workers from collective enterprises were included in the calculations, the total number increased to 30 million. ${ }^{7}$ During this time, there was a compensating surge in private employment in the industrial sector of close to thirty million workers and another six million jobs in the combined foreign and Hong Kong-Macao-Taiwan sectors. Furthermore, during 1985-2005, we see construction jobs having more than doubled from 20.4 million to nearly 42 million (NBS, 2007, p. 114).

Hence, during the 20-year period on which we focus, the principal surge in industrial employment transpired over the decade 1985-1996, during which China’s total industrial employment grew from 103.8 million to 162.0 million. During the subsequent decade, 19952005, as the composition of industrial growth and employment moved away from the state sector toward the private and foreign/overseas-funded sectors, it is likely to have also shifted from China's urban core increasingly toward the urban periphery, thus making the growth of industrial and construction employment more accessible to off-farm migrant labor.

Notwithstanding exceptionally rapid employment growth during the reform period, during 1985-95 labor productivity grew at an annual exponential rate of 8.20\%; during the next

\footnotetext{
${ }^{7}$ China Labor Bulletin, "Reform of State-Owned Enterprises in China," http://www.clb.org.hk/content/reformstate-owned-enterprises-china\#7b
} 
10-year period, 1995-2005, with slower employment growth, productivity grew at an annual rate of $8.54 \%$. Finally, during the 2005-2015, productivity grew at an annual rate of $6.93 \%{ }^{8}$. These rates are rather extraordinary. Given that during 1985-2015, Chinese industry has been converging toward the international productivity frontier, causing catch-up to be increasingly difficult, ${ }^{9}$ maintaining high levels of productivity growth is a notable achievement. The fact that employment growth was able to accelerate during the past decade even as productivity growth continue its robust rate of growth is rather impressive.

This sustained increase in labor productivity growth has translated into not only higher levels of productivity, but also higher wages. According to a 2014 survey by the Japan External Trade Organization, the total annual cost of a Chinese manufacturing worker (including salary, benefits, social security payments and bonuses) is $\$ 8,204$, compared to $\$ 4,481$ in Indonesia, $\$ 3,618$ in India, ${ }^{10} \$ 2,989$ in Vietnam, and $\$ 1,580$ in Bangladesh.

A number of inter-related features of the $21^{\text {st }}$ Century Chinese economy underscore its drive to achieve a level of technological sophistication comparable to that of its OECD counterparts. Two conditions, in particular, are enabling China's technology transformation. A key measure of China's search for more advanced technologies has been the surge in R\&D spending. China's R\&D intensity, just $0.5 \%$ in 1990 and $0.6 \%$ in 1996, commenced its surge in the late 1990s, reaching $1.8 \%$ in 2010 , rising to the current range of $2.2 \%$. As such, China is the only middleincome country to be in the 2-3\% GERD range which heretofore has been achieved only by a select group of OECD countries and smaller economies, notably Singapore and Taiwan. This intensification of R\&D spending is a measure of and harbinger of China's move up the industry technology ladder as China's leadership strives for the economy to become "a knowledge economy" and an "innovation economy." China now leads the world in patent applications. While many of these are lower quality patents, the numbers of both home-grown invention patents and invention patents is growing substantially faster than those of the U.S. Japan, and the EU.

As the World Intellectual Patent Office reported in 2015, "Patent offices receiving the highest number of applications in 2014 were China, with 928,177 filings, followed by the US $(578,802)$, Japan $(325,989)$, the Republic of Korea $(210,292)$ and the European Patent Office

\footnotetext{
${ }^{8}$ Computed by the author, based on NBS yearbook data.

"Or as Gershenkron (1966) would characterize it, the "advantages of backwardness" would diminish.

${ }^{10}$ Survey of Japanese-Affiliated Firms in Asia and Oceania (FY2014 Survey), December 2013.
} 
(EPO, 152,662)." WIPO goes on to speculate that its $12.5 \%$ growth of patent filings in 2014, China's State Intellectual Property Office (SIPO) is set to become the first office to receive a million applications in a single year. China. In terms of international patents filed abroad, US applicants filed the most applications abroad $(224,400)$, followed by those from Japan $(200,000)$ and Germany $(105,600)$. By contrast, Chinese applicants filed comparatively few applications abroad - only around 36,700. ${ }^{11}$

The second condition enabling China's industrial technology upgrading is captured as the central theme of a McKinsey and Company report (2015, p. 7). According to McKinsey, having established "the world's most extensive manufacturing ecosystem," Chinese manufacturing is able to achieve "the continuous innovations in production processes that reduce costs and improve quality.” According to McKinsey, China’s unique manufacturing ecosystem has given its manufacturing economy two major innovation advantages. The first, resulting from a combination the rapid growth of exports during 1990 to 2010 and its large and fast-growing domestic market is a large, fast-growing, and increasingly higher-income customer base that is driving its capacity for customer-focused innovation. Minor, incremental, but cumulatively significant, product innovations, such as those appearing in smart phones, renewable energy, and automobiles enable China to close in on the global cost-quality frontier across an increasingly wide rate of consumer goods. A second, related, consequence of its manufacturing ecosystem is its ability to achieve efficiency-driven innovation centered on incremental innovations that improve production efficiency. Both of these - customer-based innovation and efficiency-driven innovation - accrue through the reach and intensity of its manufacturing economy to generate both learning by doing on the factory floor and learning by using in the market place - trial, error, and customer feedback from China’s rapidly growing middle class.

A persistent myth about Chinese manufacturing is that the country is only good for assembly, with the more profitable parts of the operation, such as design and marketing, remaining in the West and Japan. However, the Economist (March 14, 2015) reported a finding of the World Bank: "The World Bank has found that the share of imported components in China's total exports has fallen from a peak of $60 \%$ in the mid-1990s to around 35\% today. This is partly because China boasts clusters of efficient suppliers that others will struggle to replicate.

\footnotetext{
${ }^{11}$ World Intellectual Property Office, "Global Patent Filings Rise in 2014 for Fifth Straight Year; China Driving Growth," Geneva, December 14, 2015, PR/2015/786.
} 
It has excellent, and improving, infrastructure:... And its firms are using automation to raise productivity, offsetting some of the effect of higher wages - the idea behind the government's new “Made in China 2025” strategy.”

Accounts of industrial upgrading through Chinese manufacturing abound. One illustrative example is that of Chu and Davis, ${ }^{12}$ which explains how Levi Strauss \& Co. began is introducing radical technology upgrades into the production of its iconic jeans in China. According to Chu and Davis, “Over the coming decades, a labor shortage will force Levi and scores of other Western brands to remake their China operations or pack up and leave. The changes will mark a new chapter in the history of globalization, where automation is king, nearness to market is crucial and the lives of workers and consumers around the world are once again scrambled.” They further recount how fearing that China will see an exodus of manufacturers, Chinese Communist Party Chief Xi Jinping last year called for "an industrial robot revolution” in China, which has become the world's largest market for automation.

Firms are also pursuing lower wages deeper into China. Foxconn once based its China operations mostly in Shenzhen, the manufacturing hub near Hong Kong. It now has large plants in Henan and Sichuan provinces, and is building a facility in Guiyang, one of China's poorest regions. Furthermore, portions of China's lower-wage production are passing to large lowincome populations in South-East Asia. However, as reported by The Economist (March 14, 2015), “...as Samsung, Microsoft, Toyota and other multinational firms trim production in China and turn instead to places such as Myanmar and the Philippines, they reinforce a regional supply chain with China at the centre.”

This account of rising productivity and rising wages, raises the question of whether rural youths who had fit into assembly line production, will be able to acquire the training, experience and skills to equip them to compete effectively in China's evolving labor market, into which increasing numbers of youths and young adults with elite high school and college degrees are entering. In the following section, we speculate on the intergenerational impacts of the transformational change in China's industrial structure and demography over the past three decades.

\footnotetext{
${ }^{12}$ Kathy Chu and Bob Davis, "End of Cheap Labor: As China's Workforce Dwindles, the World Scramble's for Alternatives," Wall Street Journal, http://www.wsj.com/articles/as-chinas-workforce-dwindles-the-worldscrambles-for-alternatives-1448293942
} 
6. The New Lost Generation: Intergenerational impacts

Section 3 above, the educational profile, affords some sense of the cost associated with the off-farm migration phenomenon. Although we do not know if the opportunity or practice of migration is itself responsible for the poor quality and limited outcomes of China's rural educational system, we find reports that the erosion of China's rural school population is compromising the quality of China's rural education. The China Daily reported the findings of a 2012 report by the Education Institute of Beijing Institute of the Technology. According to the China Daily account ${ }^{13}$ :

The number of rural school pupils has dropped to a ten year low with more than 60 schools closing every day, a report on countryside learning revealed. From 2000 to 2010, some 63 primary schools, 30 teaching schools and 3 junior schools closed on average every day in the countryside. From 2000 to 2010, the number of countryside primary school pupils decreased by 37.8 percent while the number of junior students decreased by 26.97 percent. More than 300,000 countryside schools and learning institutes closed over the same period, while 10,600 junior schools closed. The report (by) claimed the decline of the school-aged population has led to the decline of rural schools, with many parents migrating to cities to find work. (The President of the Institute), Yang Dongping...claims the large scale removal of countryside schools led to the gradual decline of rural education and excessive merging of schools, leading to long travel and high tuition fees. "The large continuous merging of schools has resulted in not only the dropout of lower grade students, but even worse, a great deal of students cannot enter school which means it is possible more than a million illiterate people will appear every year," said Han Qinglin, the inspector of Hebei Education Department and the director-general of the rural education branch of the Chinese Education Society.

In all likelihood, as China's urban-rural income inequality has grown in recent decades, enabling China's emerging urban middle class to dedicate ever more household resources to schooling their single children, it is likely that the rural-urban education quality gap has expanded further. Below, we examine certain other consequences of the pattern of migration: the impact on the children of migrants and the implications for inter-generational income inequality.

Implications for educational opportunities for migrant children. According to a 2005 survey, there were 18 million migrant children (0-14) of which one third were migrants to big cities, one third migrants to counties and towns, and one third were internal migrants within their

\footnotetext{
13 "Rural school pupils drop to 10-year low," Nov. 20, 2012, http://www.chinadaily.com.cn/china/201211/20/content 15944175.htm
} 
counties of origin. Meanwhile, as a result of adult migrants, there are 60 million children leftbehind (0-14) in their hometown. (Han, 2009)

Formal (or “permanent”) moves - meaning those involving a hukou change -- crossing city, town and township boundaries are strictly regulated and require approval by the public security authorities. Generally speaking, it is very difficult for an ordinary persons to change hukou from rural to urban areas, or from smaller cities to larger cities (Wang, 2005; Chan, 2009a). The New Compulsory Education Act which was revised to cover migrant children in 2005, nearly 20-years after it first took effect, relies on weak provisions and has yet to break through the Hukou-based registry oriented enrollment principle. Therefore, for the period 19852005, for the children of our Lost Generation, the law did not attempt to resolve the systematic barriers to educational opportunity to migrant children residing under the hukou system.

From their multivariate analysis of school enrollment, using data from Guangdong Province for the 1995 China 1\% Population Sample Survey, Liang and Chen (2007) report two major findings. First, temporary migrant children were much less likely to be enrolled in school compared to local children. Temporary migrants with less than one year of residence in cities suffered the most. Perhaps somewhat surprisingly, permanent migrant children were more likely to be enrolled in school than local children; the authors speculate that this disparity arose due largely to the highly selective nature of their parents who themselves had often had the qualities to manage a successful life transition to a new location and orchestrate their family's access to local services notwithstanding the obstacles inherent in the hukou system. Liang and Chen’s second finding is that also in rural areas, compared to non-migrant children established in a place of origin, rural temporary migrant children from Guangdong also encountered a major disadvantage in terms of school enrollment. As education has become increasingly important for socio-economic mobility in Chinese society, such disadvantages faced by temporary migrant children are likely to have detrimental and long-term consequences for migrant children and for urban society as a whole.

Chang, Dong, and MacPhail (2011) assess the impact of internal migration on the time allocation patterns of the left-behind elderly and children in rural China, 1997-2006. The proportion of children with migrating parents is increasing, with 26.6\% in 1996 having at least one parent migrating, rising to $34.4 \%$ in 2006. Their multi-variate analysis, based on data from the China Health and Nutrition Survey (CHNS), demonstrates that the migration of household 
members results in increases in the time spent on farm work and domestic work by the leftbehind elderly and children. The survey shows a rising proportion of households with one or more family members relying on the household work of elderly family members; the proportion rises from $40.0 \%$ in 1996 to $48.3 \%$ in 2006. Eighty percent or more of the time, the migrating parent is the father. The survey makes clear that the phenomenon has fundamentally altered the nature of family structure in China's rural sector, fragmenting the traditional 2-parent family structure, while disbursing the children over a depleted rural education system and second-tier migrant education system, both of which are far inferior to the range of schooling opportunities accessible to city residents. Migration has a striking gender differentiated impact, with the increase in work time being greater for elderly women and girls than elderly men and boys. Thus, the authors find that non-migrant left-behind children - the children of departed migrant patents - suffer from poorer schooling outcomes relative to intact non-migrant families.

Disparities in intergenerational educational opportunities. In 2010, China’s State Council approved an ambitious plan of nationwide education reform. ${ }^{14}$ The development of education, ranging from pre-school to vocational education in rural areas, will be a priority in the country's overall development program, according to the plan. The National Middle- and LongTerm Education Development Blueprint was meant to set the tone for enhancing the country's education sector, which has long suffered from problems ranging from funding shortage to unbalanced development between rural and urban areas. The blueprint sets the total budget for education at $4 \%$ of gross domestic product by 2012, or a 0.52 percentage point increase from 2008. The world's average was $4.5 \%$ in 2008.

The blueprint also pledges to narrow the educational gap between rural and urban areas by building more schools, providing more teachers and enrolling more high school graduates into college from rural, ethnic minority-dominated or less developed regions. Among the other features in the plan, pre-school education will be available to every citizen by 2020, at least 90 per cent of middle school graduates will continue to high school, more than 40 per cent of high school graduates will go to university, and an average citizen should receive at least 11.2 years of education.

\footnotetext{
${ }^{14}$ Reported in the South China Morning Post, "Huge Education System Upgrade," May 7, 2010, http://www.scmp.com/article/713615/huge-education-system-upgrade
} 
In 2012, nearly 25 million students in China were enrolled in high school compared with just 7 million in 1995, when the relevant age cohort was approximately 1/3 larger than it was in 2012. At the university level, in 2012 nearly 24 million were enrolled for bachelor's degrees compared with less than 3 million in 1995. Most certainly, in 1995, very few of the high school and university students were rural residents, off-farm migrants, or the children of off-farm migrants. One implication of this surge in higher-level schooling is that for the technologyenhanced jobs that are now coming on line across Chinese industry, the more than 10 million students who are emerging today from China's substantially upgraded high school and university system are far outcompeting the off-farm migrant population, now in their mid-late 20s and early 40s.

Clearly this initiative is much needed. While much needed, coming on top of the phase in of the 9-year compulsory law, the nationwide initiative to upgrade China's educational system is , however, likely to create a deeper intergenerational divide between the current and recently schooled youth and young adults, who are entering the job market with significantly upgraded skills relative to their immediately older generation. This has all the makings of a deepening and growing income gap between the pre-2005 off-farm job entrants and the recent post-2005 graduates and beyond. ${ }^{15}$

A growing burden on the future workforce. While much of the attention of demographers viewing China's demographic profile is on the growing number of elderly, the change in the age composition of the labor force over the next 20 years is also striking. Not only will the number of newly entering workers continue to decline, while the distribution of their schooling profile increasingly shifts to the right, their share of the overall labor force will decline dramatically. As older workers become increasingly technologically obsolete and underemployed, the new labor force entrants are likely to enjoy rapidly increasing incomes. Many of the new labor force entrants will be competitive on the global labor market commanding incomes consistent with the high-income range of OECD households. The result is likely to be an ever growing income divide between the New Lost Generation and this new globally integrated generation.

One implication may well be that, should it materialize with the force as suggested in this analysis, the Lost Generation becomes an increasing burden on the younger generation now

\footnotetext{
${ }^{15}$ Again, the year 2005 is arbitrary. The generational gap likely lies along a continuum beginning during the period 2000 to 2010 and deepening into the present.
} 
entering China’s more technologically advanced workforce. Moreover, as emphasized in the immediate previous section, a substantial portion of the children of the migrant families are also likely to have suffered from foreshortened, poor-quality schooling, so that like their parents, they too are likely to be disadvantaged as they struggle with a dynamically upgrading labor market. The upshot of this decline in the share of youth and new job entrants in China's workforce is a growing burden for the smaller cohort of new labor force entrants as they are expected to step up to support not only the growing number of retired elderly but also the larger numbers of the offfarm cohort of 1985-2005 - the migrants and their children - that is likely to be increasingly driven to the margin.

\section{Conclusions}

This paper may appear to be making the argument that China's off-farm migrants mistakenly chose to abandon their schooling track prematurely and separate from their families and farming by migrating in pursuit of urban-based industrial jobs. The paper cannot draw that conclusion. Numerous conditions conspired to complicate these decisions. First, we have documented the relative disrepair of China’s rural school system. After graduating from uppermiddle school, even the persevering and talented student may not have been prepared to compete for a so-called "good” job, one with a career ladder that survives into the future. More fundamentally, to remain in a comparatively backward agrarian setting would have guaranteed the lack of access to a good job.

The migration decision was typically made in an uncertain environment. Under the Household Responsibility System in which land security was tenuous under local officials and Party bosses vying for revenue and power, rural youth faced uncertainty about life prospects as a village farmer. On the other hand, the Party may have issued a decree transferring title to the heretofore lessees against the background of a relative rise in the terms of trade for agricultural goods. A key unknown, of course, was China's progress moving up the international technology ladder and the Government's prioritization of measures to facilitate that advance, including the likelihood of the disappearance of a wide swath of jobs suitable for unskilled rural youth. The point of this paper is that China's rural youth faced a set of unpleasant and high-risk choices. The off-farm migration decision may have been the better decision, but it too is likely to be part 
of a larger pattern of persistent income inequality. As a result of chronic under-education, the offarm migration surge, and now a rapidly transforming economy, the generation of migrants that transitioned China to "the world's factory” may increasingly find itself the victim of an increasingly skewed income distribution that is not so much a consequence of the rural-urban inequality of the past as the result of rising inter-generational inequality. Increasingly, China's educational elites - those with elite secondary school and university educations - are likely to reap the benefits enjoyed by China’s transformation to a "knowledge economy," resulting from OECD-like levels of R\&D intensity. Nonetheless the thickening of China's lower income tail resulting from China's New Lost Generation and its children - the households much responsible for transforming China to the "world’s factory" and creating the seeds for its technological dynamism - and the thickening of its upper tail - the beneficiaries of this intergenerational dynamic - will likely result in untold economic, social, and political challenges for the country. 


\section{Bibliography}

Caprice, Leah, (2008), “The Lost Generation of the 17th Chinese Communist Party Politburo,” A Jamestown Foundation Publication: China Brief Volume: 8 Issue: 19

October 7,

2008 http://www.jamestown.org/single/?tx_ttnews\%5Btt_news\%5D=5210\&no_cache=1\#.VxF7 $\underline{\mathrm{xTArI} 2 \mathrm{w}}$

Das, Mitali and Papa N’Diaye, 2013. “Chronicle of a Decline Foretold: Has China Reached the Lewis Turning Point?,” IMF Working Paper Research Department and Asia and Pacific Department, January 2013.

The Economist, "The end of cheap China: What do soaring Chinese wages mean for global manufacturing?” March 10th 2012. http://www.economist.com/node/21549956

, (2014), “Down and Out in Rural China,” August 23, 2014.

Fang, Tony and Lin, Carl, 2013. “Minimum Wages and Employment in China,” IZA Discussion Paper No. 7813 December 2013.

Fei, John and Gus Ranis, 1964. Development of the Labor Surplus Economy, Yale University.

Feng, Shuaizhang, Hu Tingyai, and Moffitt, Robert (2015). “Long Run Trends in Unemployment and Labor Force Participation in China,” NBER Working Paper No. 21460, Issued in August 2015

Fretham, Stephanie J. B., Carlson, Erik S., and Georgieff, Michael K., (2011), “The Role of Iron in Learning and Memory,” Advanced Nutrition, Vol. 2, March 2011, pp. 112-121.

International Labor Organization (ILO), "Labour migration in China and Mongolia,” http://www.ilo.org/beijing/areas-of-work/labour-migration/lang--en/index.htm

Giles, John, Park, Albert, and Wang, Meiyan (2015), “The Great Proletarian Cultural Revolution, Disruptions to Education, and the Returns to Schooling in Urban China,” Discussion Paper No. 8930 March 2015, Institute for the Study of Labor, Bonn.

Han, Jialing (2009), "Education for migrant children in China,” Background paper for the Education for All Global, Monitoring Report 2010

Hannum, Emily (1999). Political Change and the Urban-Rural Gap in Basic Education in China, 1949-1990 Author(s): Source: Comparative Education Review, Vol. 43, No. 2 (May, 1999), pp. $193-211$

Heckman, James, J. (2005), “China’s human capital investment,” China Economic Review Volume 16, Issue 1, Pages 50-70. 
Chang, Hongqin, Dong, Xiao-yuan, and MacPhail, Fiona, “Labor Migration and Time Use Patterns of the Left-behind Children and Elderly in Rural China,” World Development (2011)

Hu, Xiaochu (2012), , “China's Young Rural-to-Urban Migrants: In Search of Fortune, Happiness, and Independence,” Migration Policy Institute, January 4, 2012.

Lewis, Arthur (1954). “Economic Development with Unlimited Supplies of Labour.”Manchester School 22 (May): 139-191.

Liang, Zai and Chen, Yiu Por, (2007). "The educational consequences of migration for children in China,” Social Science Research, Volume 36, Issue 1, March 2007, Pages 28-47

Lewis, Arthur. (1955), The Theory of Economic Growth. London: Allen and Unwin

Lin, Justin Yifu (1987), “The Household Responsibility System Reform in China: A Peasant's Institutional Choice,” American Journal of Agricultural Economics, Vol. 69, No. 2, pp. 410-415.

Lin, Justin Yifu (1989) “Rural Reform and Agricultural Productivity in China,” UCLA Working Paper No. 576, December 1989.

McKinsey and Company (2015). The China Effect on Global Innovation, October, 2015

National Bureau of Statistics, China Statistical Yearbook, China Statistics Press, Beijing, various years.

Naughton, Barry. (2007). The Chinese Economy: Transitions and Growth. Cambridge: MIT Press.

Wall Street Journal, “As China’s Workforce Dwindles, the World Scrambles for Alternatives,” http://www.wsj.com/articles/as-chinas-workforce-dwindles-the-world-scramblesfor-alternatives-1448293942

Yang, Dennis Tao and Li, Yuanfang (2008), Agricultural price reforms in China: Experience from the past three decades. Agroalimentaria 14(27):13-23 • November 2008

Zhang, Linxiu, Huang, Jikun, Rozelle, Scott D., (2002). “Employment, Emerging Labor Markets, and the Role of Education in Rural China,” Agriculture and Resource Economics Working Papers, 04-01-2002, http://escholarship.org/uc/item/1dx4c7bj 
Figure 4

China: Per capita grain output and food availability,

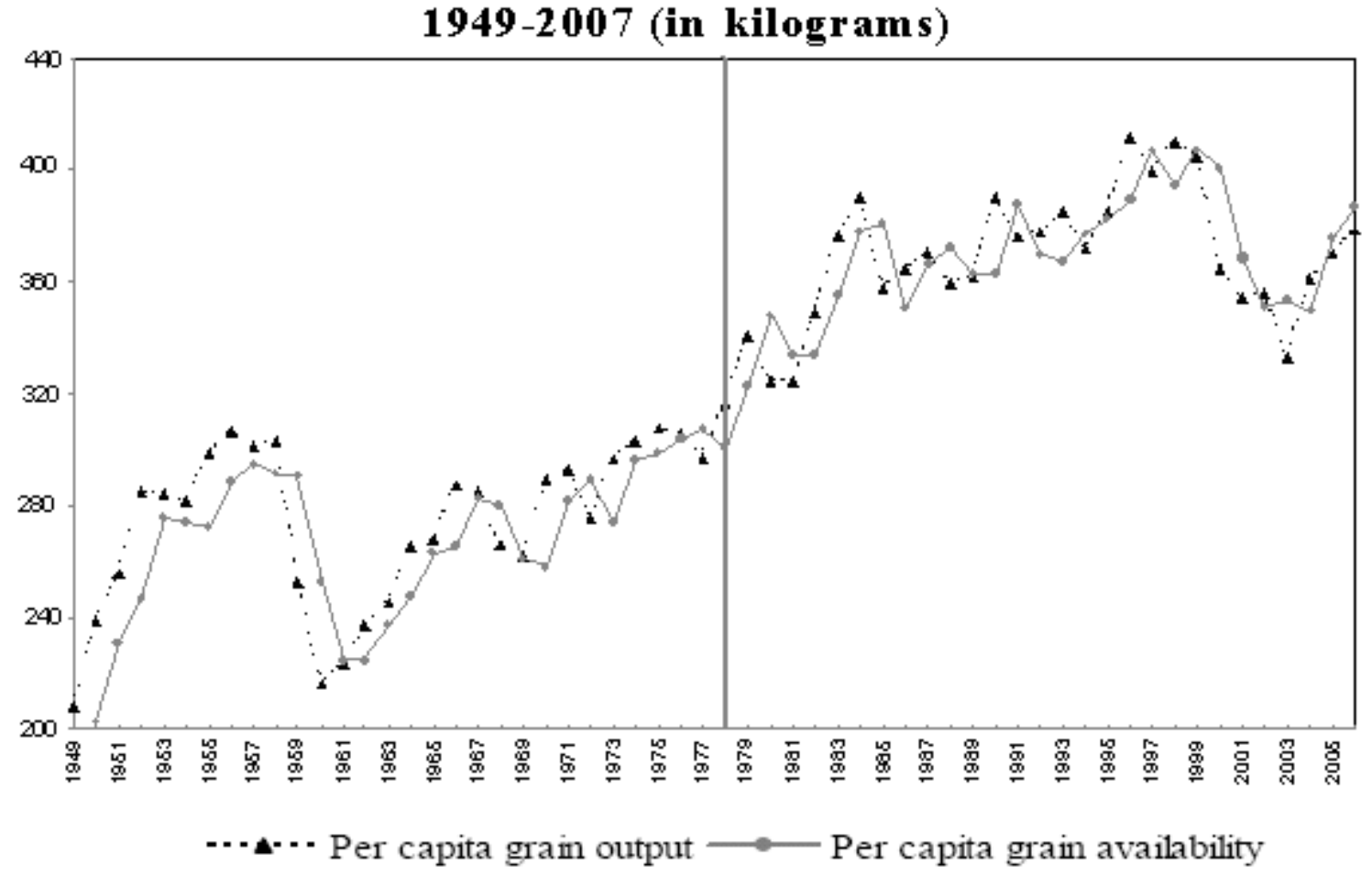

Source: Yang and Li (2008) 


\section{Figure 1}

\section{Chin a: Price indexes of farm input and output, 1951-2006}

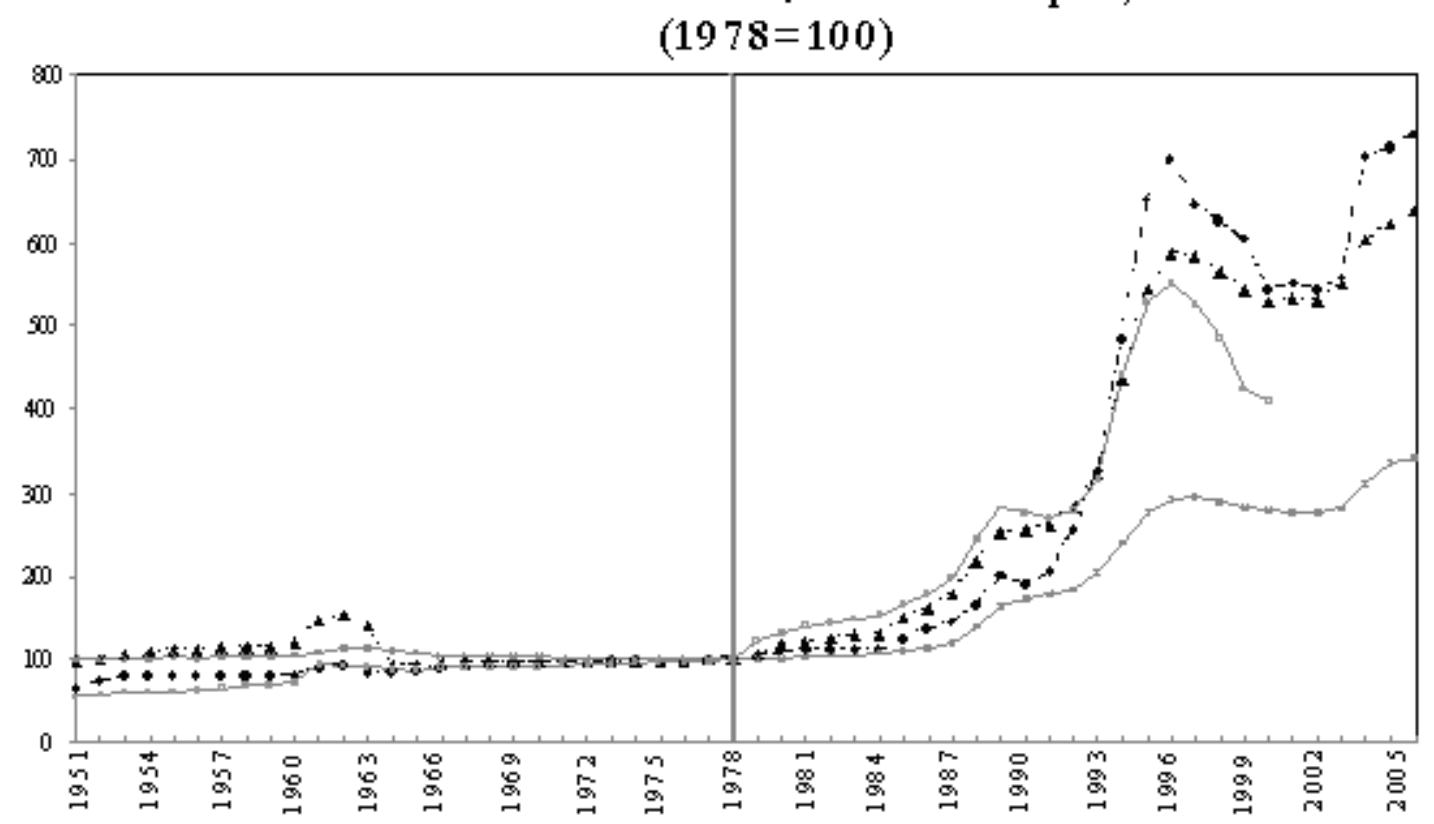

..... Retail price index of food - - - Retail price index of grain

$\longrightarrow$ Procurement price index of farm products $\longrightarrow$ Rural industrial price index

Source: Yang and Li (2008

\begin{tabular}{|l|l|l|l|l|}
\hline \multicolumn{5}{|c|}{ Table 1. Junior Secondary Graduation } \\
\hline & $\begin{array}{l}\text { junior } \\
\text { secondary } \\
\text { graduates }\end{array}$ & $\begin{array}{l}\text { Population } \\
0-14\end{array}$ & $\begin{array}{l}\% \text { of total } \\
\text { population }\end{array}$ & $\begin{array}{l}\text { graduates \% } \\
\text { of age group }\end{array}$ \\
\hline 1982 & 964.7 & 3414.6 & 33.6 & 28.3 \\
\hline 1987 & 1119.3 & 3134.7 & 28.7 & 35.6 \\
\hline 1990 & 1109.1 & 3165.9 & 27.7 & 35.0 \\
\hline 1995 & 1227.4 & 3221.8 & 26.6 & 38.1 \\
\hline 2000 & 1607.1 & 2901.2 & 22.9 & 55.3 \\
\hline 2005 & 2106.5 & 2794.7 & 21.5 & 75.4 \\
\hline 2010 & 1748.6 & 2225.9 & 16.6 & 76.6 \\
\hline Source: NBS (2012) & \multicolumn{4}{l}{} \\
\hline
\end{tabular}




\begin{tabular}{|l|l|l|l|l|l|l|}
\hline \multicolumn{7}{|c|}{ Table 2, School enrollments } \\
\hline & $\begin{array}{l}\text { Primary } \\
\text { enrollments }\end{array}$ & $\begin{array}{l}\text { Primary } \\
\text { graduates }\end{array}$ & $\begin{array}{l}\text { Junior } \\
\text { secondary } \\
\text { enrollments }\end{array}$ & $\begin{array}{l}\text { No. graduating } \\
\text { 3 years later }\end{array}$ & $\begin{array}{l}\% \\
\text { graduating }\end{array}$ \\
\hline 1978 & 3315.4 & 2287.9 & 2006.0 & & $964.8(1980)$ & \\
\hline 1980 & 2943.3 & 2053.3 & 1557.6 & & $1007.2(1985)$ & \\
\hline 1985 & 2298.2 & 1999.4 & 1349.9 & 67.4 & 1157.2 & $85.4(57.6)$ \\
\hline 1986 & & 2016.1 & 1386.6 & 68.7 & 1134.3 & $81.8(56.2)$ \\
\hline 1987 & & 2043.0 & 1394.3 & 68.2 & 1109.1 & $80.0(54.3)$ \\
\hline 1988 & & 1930.3 & 1340.5 & 69.4 & 1085.5 & $81.0(56.2)$ \\
\hline 1989 & & 1857.1 & 1309.4 & 70.5 & 1102.3 & $84.2(59.4)$ \\
\hline 1990 & 2064.0 & 1863.1 & 1369.9 & 73.5 & 1134.2 & $82.8(63.7)$ \\
\hline 1995 & 2531.8 & 1961.5 & 1752.3 & 89.3 & 1580.2 & $90.2(80.5)$ \\
\hline 2000 & 1946.5 & 2419.2 & 2263.3 & 93.6 & 1995.6 & $88.2(82.5)$ \\
\hline 2005 & 1671.7 & 2019.5 & 1976.5 & 97.9 & 1862.9 & $94.2(92.3)$ \\
\hline 2010 & 1691.7 & 1739.6 & 1715.5 & 98.6 & 1561.5 & $91.0(89.7)$ \\
\hline Source: NBS (2012) & & & & \\
\hline
\end{tabular}

Table 8-2: Educational Attainment of Population, 15 and Above

\begin{tabular}{lcccc}
\hline & 1982 & 1990 & 1995 & 2000 \\
\hline Illiterate, Semi-literate & $34.5 \%$ & $18.5 \%$ & $13.6 \%$ & $9.1 \%$ \\
Elementary & $30.8 \%$ & $43.2 \%$ & $43.6 \%$ & $71.7 \%$ \\
Lower Middle & $23.8 \%$ & $27.2 \%$ & $31.0 \%$ & \\
Upper Middle & $10.0 \%$ & $9.4 \%$ & $9.4 \%$ & $14.5 \%$ \\
College & $0.9 \%$ & $1.7 \%$ & $2.3 \%$ & $4.7 \%$ \\
\hline
\end{tabular}

Source: 1982 Census Summary Volume, p. 360

China Population Statistics Yearbook 1996, pp. 5, $154-55$.

2001 Almanac of China's Population, p. 147; 2002 Statistical Yearbook, p. 110.

2000 are preliminary calculations.

Source: Naughton (2007) 


\section{Where Do People Fail To Attain A High School Qualification?}

$\%$ of 25-34 year-olds with an education level below upper secondary in selected countries*

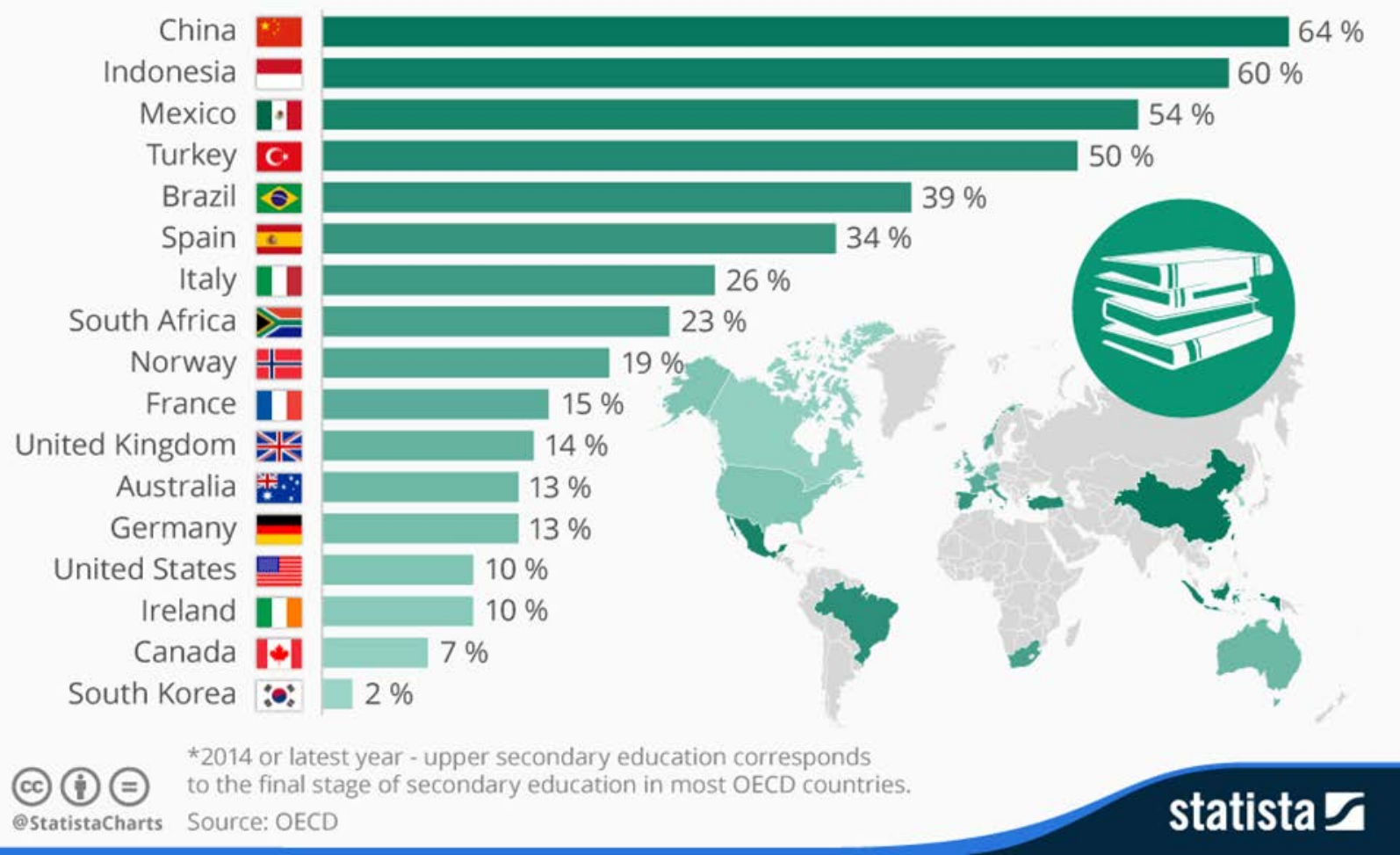

Table 2. Level of education for rural population between 1988-1996

\begin{tabular}{lccc}
\hline Education level & $\mathbf{1 9 8 8}$ & $\mathbf{1 9 9 2}$ & $\mathbf{1 9 9 6}$ \\
\hline \multirow{2}{*}{ Total } & 5.33 & 6.10 & 5.20 \\
& $(3.78)$ & $(3.61)$ & $(3.69)$ \\
Male & 6.51 & 7.30 & 6.64 \\
& $(3.49)$ & $(3.12)$ & $(3.04)$ \\
Female & 3.92 & 4.72 & 3.63 \\
& $(3.63)$ & $(3.64)$ & $(3.72)$ \\
\hline
\end{tabular}

Source: Author's survey.

Note: Figures in brackets are the standard deviations.

Zhang, Rozelle et al (2002) 
FIGURE 3.6 Distribution of educational readiness test scores for children at age 4-5, Urban (top panel) and rural (bottom panel) China

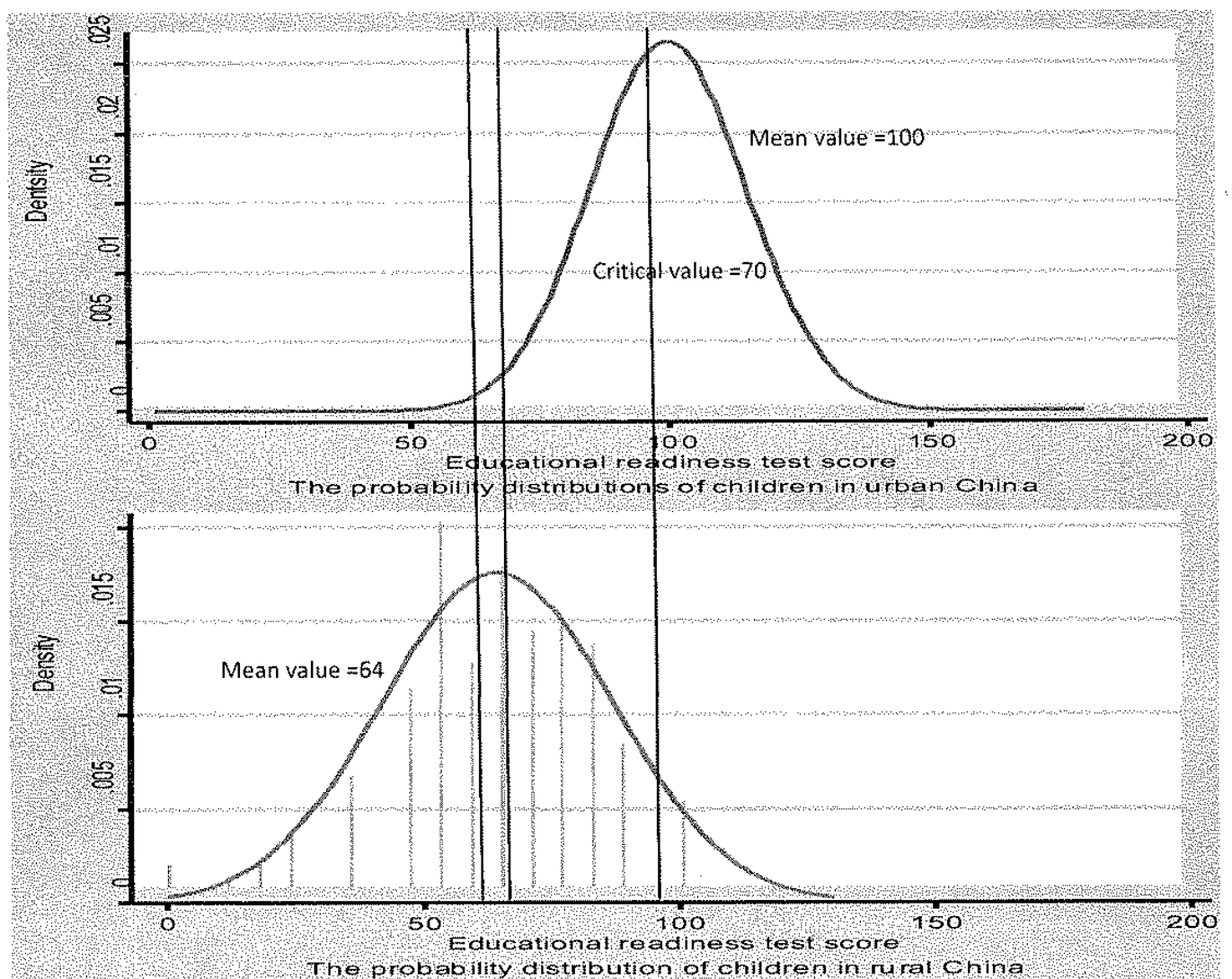

Sources: Data in top panel, Ou, 2007. Data in bottom panel, Rozelle (2011) for Gansu, Henan and Shaanxi.

FIGURE 3.2 Anemia prevalence in rural children under 5 years of age, in months $(\%)$
Figure 3.3 Anemia prevalence in children under 5 years of age in rural poor areas, in months $(\%)^{33}$

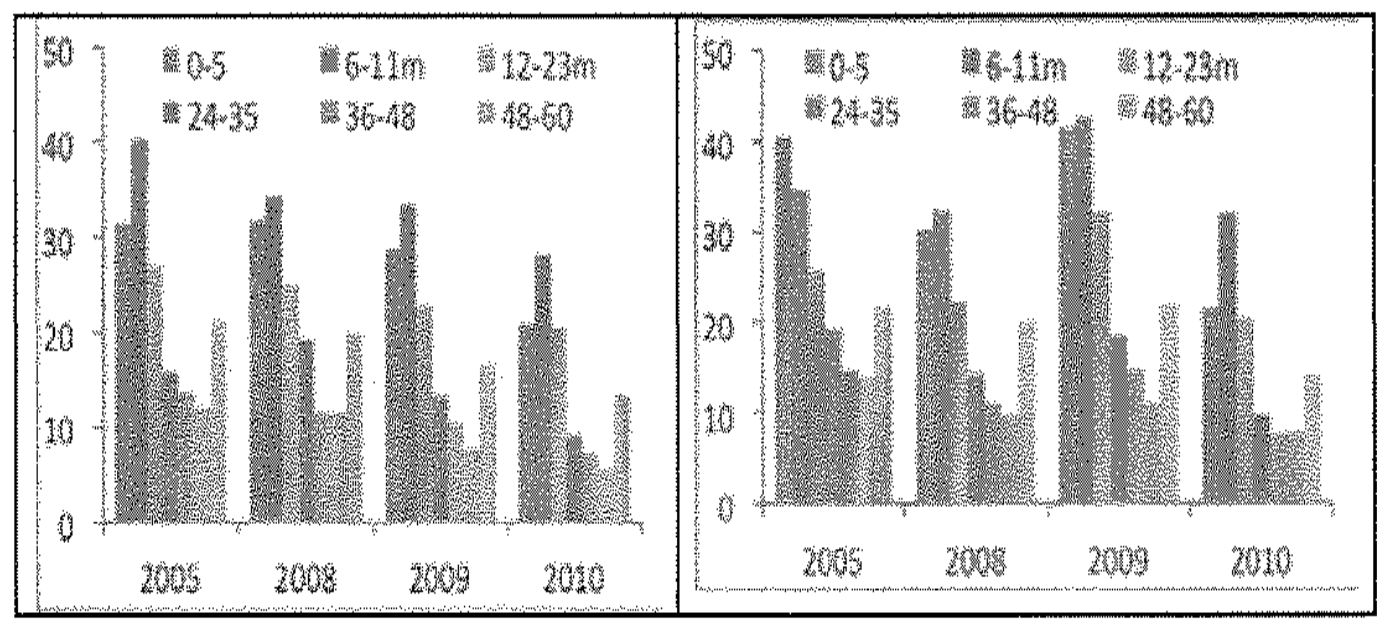

Source: CHNS various years.

Source: CHNS, various years. 


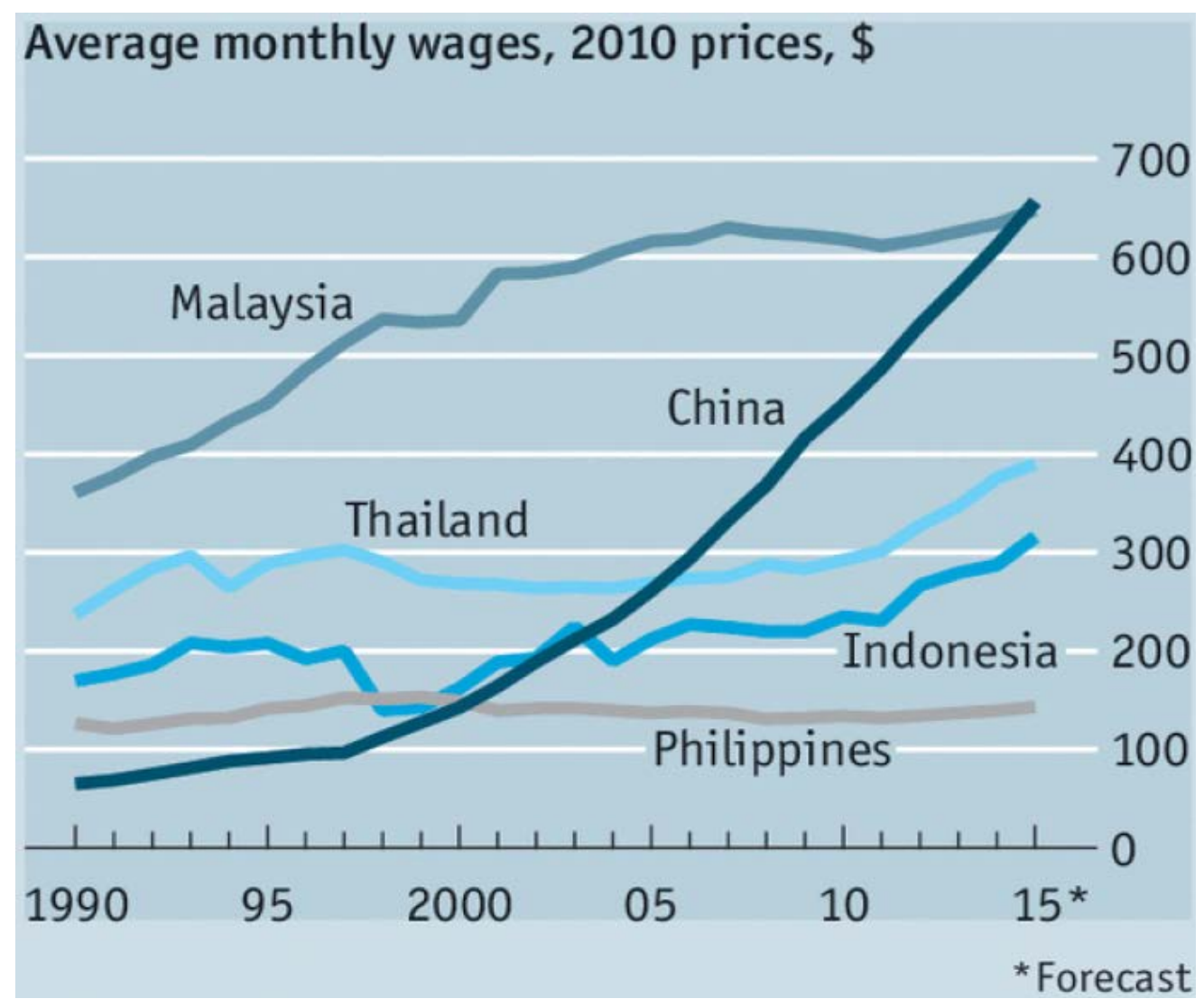

Source: The Economist, “The Tightening Grip,” March 14,

2015, http://www.economist.com/news/briefing/21646180-rising-chinese-wages-will-onlystrengthen-asias-hold-manufacturing-tightening-grip 